\title{
GERMAN-AUSTRIAN RECOMMENDATIONS FOR HIV1-THERAPY in Pregnancy and in HIV1-exposed Newborn - UPDATE 2008
}

\author{
Common declaration* \\ of \\ The German AIDS-society (DAIG) \\ The Austrian AIDS-society (OEAG) \\ of the HIV-AIDS competence network \\ as well as \\ The Robert-Koch Institute Berlin (RKI) \\ The German Association of Physicians specialized in HIV Care (DAGNAE) \\ The German Society of Pediatric and Youth Medicine (DGKJ) \\ The German AIDS Pediatric Association (PAAD) \\ The German Society of Obstetrics and Gynecology (DGGG) \\ The National Reference Center for Retroviruses (NRZ) \\ German AIDS Assistance (DAH)
}

Updated by

Dr. med. Bernd Buchholz (University Medical Centre Mannheim, Pediatric Clinic), Dr. med. Matthias Beichert (Mannheim, Gynecology and Obstetrics Practice), Dr. med. Ulrich Marcus (Robert Koch Institute, Berlin), Dr. med. Thomas Grubert, Dr. med. Andrea Gingelmaier (Gynecology Clinic of the Ludwig Maximilians University of Munich) Dr. med. Annette Haberl (HIV-Department, J. W. Goethe-University Hospital, Frankfurt) and Dr. med. Brigitte Schmied (Otto-Wagner Spital, Vienna)

\footnotetext{
* In July 2008 the following recommendations were sent for discussion per e-mail to the participants/specialists as per particulars given below and to all members of the German AIDS-society (DAIG). The final version was prepared on the occasion of a consensus building conference in Cologne on September 5th 2008.
}

The specialists included (in alphabetical order):

Beichert M (Mannheim) Bogner J (München) Brockmeyer N (Bochum) Buchholz B (Mannheim) Cordes C (Berlin) Feiterna-Sperling C (Berlin) Funke A-M (Bremen) Gingelmaier A (München)
Graefe K (Hamburg) Gröger S (Hamburg) Grosch-Wörner I (Berlin) Grubert T (Ravensburg) Gürtler L (Frankfurt) Haberl A (Frankfurt) Hien S (Mannheim) Hollwitz B (Hannover)
Kästner R (München) Königs C (Frankfurt) Korn K (Erlangen) Kremer H (Miami) Marcus U (Berlin) Niehues T (Krefeld) Öttinger A (Linz) Reitter A (Frankfurt)
Schafberger A (Berlin) Schleehauf D (Berlin) Schmied B (Wien) Sonnenberg-Schwan U (München) Stögerer M (Graz) Vocks-Hauck M (Berlin) von Weizäcker K (Berlin) 


\section{Abstract:}

German-Austrian recommendations for HIV1-therapy in pregnancy - Update 2008

Bernd Buchholz (University Medical Centre Mannheim, Pediatric Clinic), Matthias Beichert (Mannheim, Gynecology and Obstetrics Practice), Ulrich Marcus (Robert Koch Institute, Berlin), Thomas Grubert, Andrea Gingelmaier (Gynecology Clinic of the Ludwig Maximilians University of Munich), Dr. med. Annette Haberl (HIV-Department, J. W. Goethe-University Hospital, Frankfurt), Dr. med. Brigitte Schmied (Otto-Wagner Spital, Wien).

In Germany during the last years about 200-250 HIV1-infected pregnant women delivered a baby each year, a number that is currently increasing. To determine the HIV-status early in pregnancy voluntary HIV-testing of all pregnant women is recommended in Germany and Austria as part of prenatal care. In those cases, where HIV1-infection was known during pregnancy, since 1995 the rate of vertical transmission of HIV1 was reduced to $1-2 \%$.

This low transmission rate has been achieved by the combination of anti-retroviral therapy of pregnant women, caesarean section scheduled before onset of labour, anti-retroviral post exposition prophylaxis in the newborn and refraining from breast-feeding by the HIV1-infected mother. To keep pace with new results in research, approval of new anti-retroviral drugs and changes in the general treatment recommendations for HIV1-infected adults, in 1998, 2001, 2003 and 2005 an interdisciplinary consensus meeting was held. Gynaecologists, infectious disease specialists, paediatricians, pharmacologists, virologists and members of the German AIDS Hilfe (NGO) were participating in this conference to update the prevention strategies. A fifth update became necessary in 2008. The updating process was started in January 2008 and was terminated in September 2008. The guidelines provide new recommendations on the indication and the starting point for HIV-therapy in pregnancies without complications, drugs and drug combinations to be used preferably in these pregnancies and updated information on adverse effects of anti-retroviral drugs. Also the procedures for different scenarios and risk constellations in pregnancy have been specified again.

With these current guidelines in Germany and Austria the low rate of vertical HIV1-transmission should be further maintained.

Key words: Pregnancy, HIV-therapy, HIV-status, HIV-testing, anti-retroviral drugs, recommendations

\section{INTRODUCTION}

The German-Austrian recommendations for HIV1therapy in pregnancy reflect the current international knowledge and the experience of German clinical settings specialized in the treatment of HIV1-positive pregnant women.

Even though all constellations, scenarios and contingencies of a pregnancy can not be considered within the scope of these recommendations, they are designed as scientifically-based guidelines. The most important and most frequent questions and problems which doctors, who treat HIV1-positive expectant mothers are facing, irrespective of whether they are experienced in the care for such pregnancies or not, are covered in these guidelines.

The medical measures recommended in these guidelines are helpful for every health care professional, who advises a HIV1-positive pregnant woman. Therefore these recommendations should be available in every delivery room. In case of obstetric emergencies the tables of these recommendations can be used as emergency plan.

It is also urgently recommended, that an HIV post-exposure prophylactic emergency set be kept in stock by the hospital and that all medical personnel involved is informed about indications and procedures related to HIV post-exposure prophylaxis after occupational HIV1-exposure (e.g. following needle prick or knife injuries to the operating surgeon).

Therapeutic recommendations can never replace extensive experience with patients and their specific problems. Therefore antenatal care of HIV1-positive expectant mothers, considering the many uncertainties associated with pregnancy, should be performed in or in cooperation with specialized centers.

Without any medical measures to prevent mother to child transmission of HIV1 up to $40 \%$ of the HIV1exposed newborn are HIV1-infected. In those cases, where HIV1-status of the pregnant women was known during pregnancy, since 1995 the rate of vertical transmission of HIV1 was reduced to $1-2 \%$ in Germany and Austria [140]. This low transmission rate has been achieved by the combination of anti-retroviral therapy of pregnant women, caesarean section scheduled before onset of labour, anti-retroviral post exposition prophylaxis in the newborn and refraining from breast-feeding by the HIV1-infected mother.

All measures necessary for the prevention of vertical HIV1-transmission can only be employed, if the HIV infection status of the expectant mother is known. Risk factors for an HIV-infection, such as origin from a an HIV epidemic region, current or previous intravenous drug abuse or sexual intercourse with an HIV-infected partner, can not always be identified amongst all pregnant HIV1-infected individuals. For that reason an HIV antibody test should be offered to every pregnant women together with competent personal counseling in regard to possible consequences in the case of a positive test result (see also in 2007 updated German prenatal care guidelines und the therefore created leaflet "HIV-testing in pregnancy" as information of all pregnant women). If necessary this must be carried out with an interpreter and cultural mediation, even if the patient needs to be referred to a specialized center for this purpose. By German law the explicit approval of the pregnant mother is required for HIV-testing, which routinely consists of an ELISA screening test. A positive test result must be confirmed by Western Blot $[1,2]$. If the patient is counseled by her gynecologist alone, addresses and telephone numbers of additional experts should be made available to the expectant mother. The personal and medical consequences of any positive test result for the woman should also be discussed in the counseling. Furthermore a competent pediatrician should con- 
tribute to the counseling about transmission risks, follow-up tests and the course of HIV1-infection in a child.

As with many other problems in pregnancy, the welfare of the child must be weighed up against that of the mother when deciding for therapeutic/prophylactic measures against HIV1.

The goals of interdisciplinary co-operation between general practitioners, obstetricians and pediatricians in the treatment of HIV1-infected expectant mothers and HIV1-exposed newborns are: 1) the prevention of mother to child transmission of HIV, and 2) the optimal treatment of pregnant women combined with minimal adverse effects in the expectant mother and in the unborn child.

Mothers with a high viral load and/or low t-helper cell numbers transmit HIV1 more frequently to their children $[3,4,5]$, therefore successful therapy of the mother is also beneficial for the child. Risks for the child that might arise from intrauterine exposure to anti-retroviral combination therapies are still uncertain since data regarding pharmacokinetics, pharmacodynamics, embryotoxicity and fetotoxicity of these drugs are lacking $[6,7,8,9,10,11,12,13]$.

Basic and clinical research data suggest multiple risk factors which contribute to vertical HIV1-transmission $[3,4,14,15,16,17,18,19,20,21,22,23,24,25]$. Combined interventions as described in the following chapters can reduce the HIV1-transmission rate below $2 \%[16,26,27,28]$.

The recommendations for diagnostic and therapeutic procedures given here are based on published study results wherever these were available. Such study results, however, are not available for all practical problems and questions, so that often clinical experience and expert opinions must be resorted to.

Even if the goal of these recommendations is the optimal treatment of mother and child based on the most recent findings, it should be stressed that the decision for the recommended diagnostic and therapeutic measures ultimately must be made in agreement with the expectant mother. This means that a refusal of a recommended diagnostic and/or therapeutic measure must also be respected, wherever the consent of an expectant mother can not be acquired despite adequate counseling.

After a detailed analysis of data and publications, a number of procedures were developed for specific situations. Most common situations and scenarios were considered. For all other situations however, individual decision on a case-by-case basis are necessary.

The following situations were discussed and consensus recommendations were made:

\section{Prenatal care}

2. Indication for anti-retroviral treatment and therapeutic regimens during pregnancy

2.1 Indication for anti-retroviral treatment

2.2 Resistance testing

2.3. Initial therapeutic regimen

2.4. Management of HIV1-positive pregnant women with Hepatitis-co-infection

2.4.1 Management of HIV1-positive pregnant women with Hepatitis B virus (HBV) co-infection

2.4.2 Management of HIV1-positive pregnant women with Hepatitis C virus (HCV) co-infection

2.5 Interruption of anti-retroviral therapy during the 1st trimester of the pregnancy

3. HIV1-transmission prophylaxis with standard risk profile

4. Risk-adapted transmission prophylaxis

4.1 Multiple pregnancy, premature labor and premature infants $33^{\text {rd }}(+0)-36^{\text {th }}(+6) \mathrm{GW}$ and maternal viral load 3000- 10000 HIV-copies/ $\mathrm{ml}$ before birth

4.2 Amnion infection syndrome/amnionitis, (premature) rupture of membranes $>4 \mathrm{~h}$, premature birth $<33^{\text {rd }}(+0)$ $\mathrm{GW}$ and viral load increase at the end of pregnancy $>10000 \mathrm{HIV}$ copies/ml

4.3 Incision injury of the child/ aspiration and/or ingestion of blood contaminated amniotic fluid

5. Procedures with incomplete transmission prophylaxis

5.1 With verified HIV1-infection

5.2. Situations with unclear HIV1-infection status

6. Mode of delivery

7. Postnatal care in the delivery room

8. Postnatal prophylaxis of the newborn

9. Refraining from breast-feeding

10. Postnatal care of the HIV1-exposed child and preparation of a surveillance register

11. Phone-Hotline, notification of unexpected observations and experiences

Table 1. Grading of the therapeutic recommendations.

\begin{tabular}{l|c|c|c}
\hline & $\begin{array}{c}\text { I } \\
\text { On the basis of at least one } \\
\text { randomized study with } \\
\text { clinical end points }\end{array}$ & $\begin{array}{c}\text { II } \\
\text { On the basis of surrogate } \\
\text { marker studies }\end{array}$ & $\begin{array}{c}\text { According to expert } \\
\text { opinion }\end{array}$ \\
\hline A Unambiguous recommendation & A I & A II & A III \\
B In general advisable & B I & B II & B III \\
C Justifiable & C I & C II & D III \\
D In general not recommended & D I & E II & III III \\
E Unambiguously not recommended & E I & E II & D \\
\hline
\end{tabular}

* Clinical end point studies for new substances are no longer carried out due to the fact that conditions for licensing by the FDA and the EMEA have changed 
The recommendations were graded as outlined in the German-Austrian guidelines for the anti-retroviral Therapy of HIV1-infection [29]. Unless the results of voting are indicated, the recommendation was agreed upon unanimously.

\section{Prenatal CARE}

Upon diagnosis of HIV1 in a pregnant woman, an interdisciplinary center specialized in HIV care should be contacted immediately. From that point onwards the woman should be treated in close cooperation with the gynecologist familiar to the pregnant women. The gynecologist, who usually treats the women, is primarily recommended to carry out the conventional prenatal care for HIV1-positive pregnant women, according to current antenatal care guidelines, to preserve the bond with the patient's familiar environment. Any other additional care measures should also be fitted in this setting. With the help of a well-planned time scheduling a closely-knit monitoring can be ensured.

Psychosocial care should be provided to each HIV1-positive expectant mother, at the latest in the HIV-specialized centers, and the opportunity to contact women's AIDS self-help groups should also be offered. In the HIV-specialized centers the patients should be fully counseled regarding maternofetal transmission risks, current therapeutic options, the possibility to reduce mother-to-child HIV1-transmission rates, existing residual risks, potential short - and long-term effects of intrauterine exposure to antiretroviral therapy for the child as well as the necessity of postnatal prophylaxis in the child and of avoiding breast-feeding. [30, 31, 32]. Considering the rapidly developing state of knowledge regarding HIV, up to date information is only warranted in such specialized centers. To overcome language barriers the help of interpreters should be obtained wherever necessary to ensure that all information reach the patients.

In co-operation between the general practitioner, the gynecologist, the obstetrician, the pediatrician and the patient, an individual, risk-adapted anti-retroviral treatment or prophylaxis concept corresponding to current German-Austrian guidelines for therapy in pregnancy should be set up. The general practitioner/infectious disease specialist should be consulted to adapt this therapeutic plan to ongoing therapies or prophylaxes against opportunistic infections. A switching of the treatment regime during pregnancy or the initiation of new therapeutic measures should only be undertaken upon consultation with a physician or center specialized in anti-retroviral therapy.

In the case of therapy-refractory morning sickness/emesis gravidarum all anti-retroviral medications should be stopped simultaneously (An interruption of a combination of 2NRTI + NNRTI is problematic: Because of their short half-value period the 2NRTI disappear very fast after simultaneous interruption. In contrast to them the NNRTI has a longer half life with a high interindividual variability. NNRTI can be detected up to 3-4 weeks after interruption in some patients [141], which after disappearance of NRTI's implies a monotherapy with a high risk of development of resistance. See also 2.5) and reintroduced si- multaneously, if the symptoms start to improve again in order to prevent the development of resistance anti-retroviral drugs (AIII).

Concurrently with the therapy, a monthly monitoring of blood counts is also recommended (AIII). Changes in blood counts are particularly significant because of the possibility of zidovudine-induced anemia and thrombocytopenia. If the hemoglobin-values drop to less than $10 \mathrm{mg} / \mathrm{dl}$ in the expectant mother, it must be decided in close cooperation with the general practitioner whether waiting with closely-knit controls is possible or if the anti-retroviral regimen must be changed.

An oral glucose tolerance test is recommended between the $23^{\text {rd }}(+0)$ and $27^{\text {th }}(+7)$ weeks of gestation (GW) to screen for pregnancy-related diabetes, particularly if the expectant mother is treated with protease inhibitors (under protease inhibitor therapy diabetes mellitus occurs approximately three times more frequently) [33] (AIII). Measurements of blood lactate, liver enzymes, lipase and LDH should be carried out at the beginning of the pregnancy, after starting a therapy or prophylaxis, with suspicious clinical symptoms (signs of lactate acidosis such as nausea, severe vomiting, abdominal pain, fatigue, raised liver values) and particularly in the $3^{\text {rd }}$ trimester because of the increased risk of lactate acidosis at the end of pregnancy (AIII).

Immunological and virological parameters (lymphocyte subsets, HIV1 viral load) should be checked at least bimonthly (AIII). The last measurement of HIV1-viral load before birth should be performed in time (2-4 weeks before birth), that the result is known at the latest at birth. In the case of an increased HIV1viral load of the mother it is possible to intensify the anti-retroviral prophylaxis of the HIV1-exposed newborn to reduce the increased risk of vertical HIV1transmission (see also 4.2) [72].

The expectant mother should be informed about any possible side effects and symptoms of the antiretroviral therapy and should also be requested to inform their general practitioner immediately of any suspicious complaints [34, 35, 36]. Furthermore, she should also be requested to consult her general practitioner before taking any other prescribed or OTC medications during the pregnancy because of potential interactions with the anti-retroviral therapy (e.g. benzodiazepines).

Especially HIV1-positive pregnant women on methadone substitution or with drug abuse should be informed in detail about drug interactions between these drugs and anti-retroviral therapy/prophylaxis. Without continuous medical evaluation anti-retroviral therapy can lead to withdrawal syndrome, which jeopardize success of anti-retroviral therapy due to lack of adherence.

A comprehensive diagnostic evaluation and therapy for genital infections is also important. Local co-infections such as chlamydiasis, trichomoniasis and bacterial vaginosis amongst others correlate with higher HIV1-transmission risks, especially due to potential induction of premature labor [24]. The following examinations are obligatory: determination of vaginal secretion $\mathrm{pH}$; sampling of a native preparation and micro- 
Table 1. (Additional) Diagnostic measures during a uncomplicated HIV1 pregnancy.

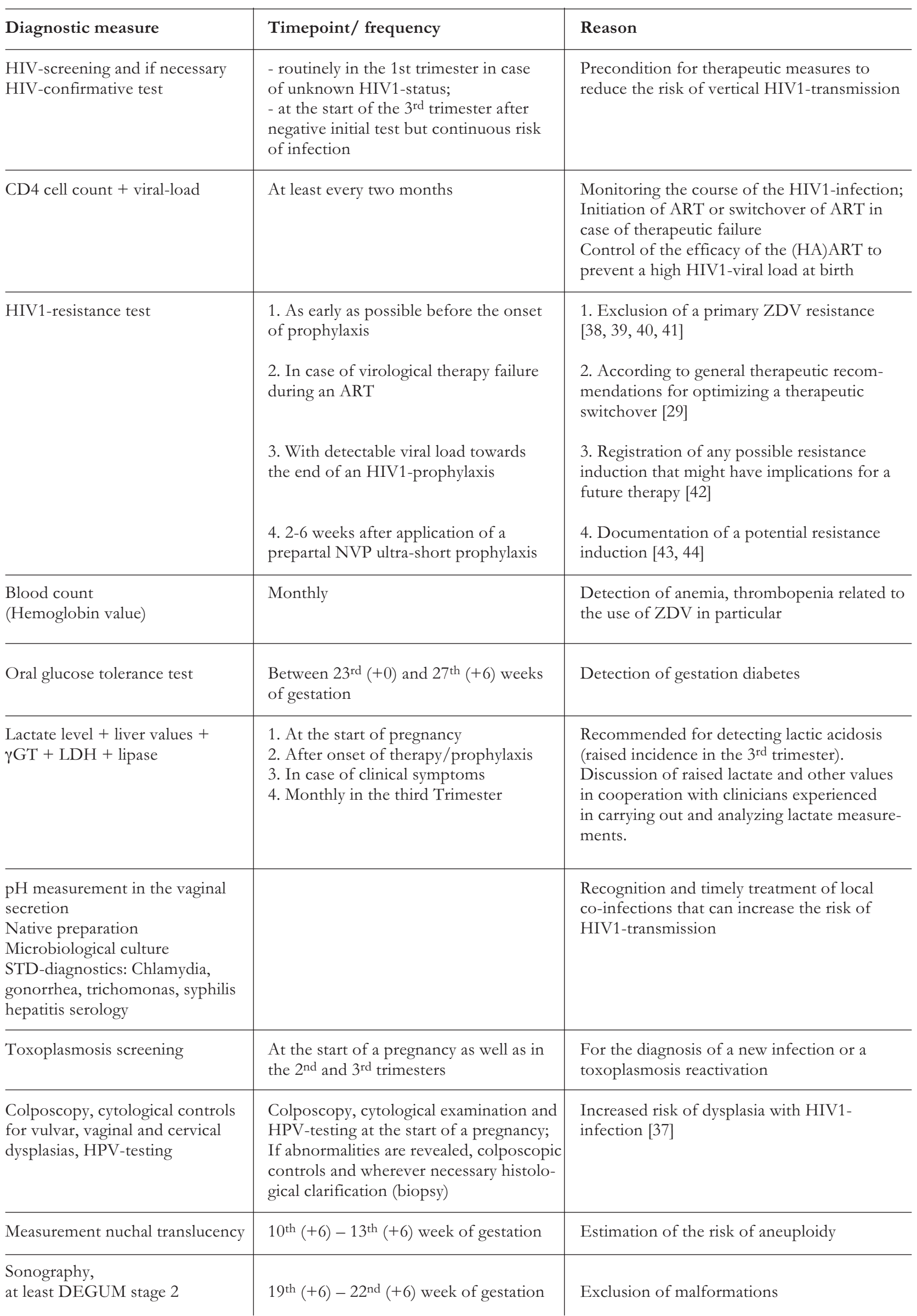


biological culturing; STD diagnostics; toxoplasmosis screening at the start of therapy and in the second and third trimester to exclude a reactivation and/or new infection at the end of the pregnancy; a complete hepatitis serology. Urinary tract infections should be excluded e.g. by Uricult examinations.

Up to $30 \%$ of HIV1-infected women display vulvar, vaginal and cervical dysplasias, which can progress more rapidly to carcinoma as a result of the HIV1-induced immune suppression [37]. For this reason a colposcopic examination should be carried out at the onset of pregnancy in addition to pap smear testing of the cervix and HPV-testing for high-risk-HPV-subtypes. If the colposcopic examination and HPV-testing yield normal results, the next control examination can be scheduled in a postnatal appointment. Any abnormalities must be controlled colposcopically and if necessary histologically (AIII). The perianal region should be examined in addition to the vulva, vagina and cervix, as also recommended for non-pregnant HIV1-infected women.

For all HIV1-infected expectant mothers nuchal translucency/transparency of fetus should be measured between the $10^{\text {th }}(+6)$ and $13^{\text {th }}(+6)$ weeks of gestation to estimate risks of aneuploidy. Fetal sonography (at least DEGUM stage 2 ) should be carried out between the $19^{\text {th }}(+6)$ and $22^{\text {nd }}(+6)$ weeks of gestation to screen for fetal malformations.

Invasive prenatal diagnostics should be avoided whenever possible. If there is an urgent indication, it should be performed with consideration of viral load and only under the protection of anti-retroviral therapy/prophylaxis because of the risk of contamination of the amniotic fluid [110,111] (AIII).

If the HIV-status of the mother is unknown and invasive prenatal diagnostic is indicated, an HIV-test should be offered again.

6-8 weeks after birth a detailed counseling about contraceptional methods is obligatory.

\section{INDICATION FOR ANTI-RETROVIRAL Treatment and Therapeutic Regimens DURING PREGNANCY}

\subsection{INDICATION FOR ANTI-RETROVIRAL TREATMENT}

Treatment indications [30] for adult HIV1-patients also apply to pregnant women (but check $3.1 \mathrm{~b} !$ !), i.e. in clinically asymptomatic women the immunological threshold for treatment is reached at a CD4-cell count below $350 \mathrm{CD} 4+$ cells $/ \mathrm{mm}^{3}$. It should be noted here that a certain degree of immunosuppression is induced physiologically by a pregnancy $[20,47]$ so that the CD4-values drop by around $10-20 \%$ during every pregnancy. In an HIV1-infected woman, this effect is may be even more pronounced (up to $40 \%$ ). (AIII)

\subsection{RESISTANCE TESTING}

In order to ensure the efficacy of anti-retroviral prophylaxis/ therapy during pregnancy, testing for preexisting resistance is generally indicated for every treatment naive pregnant woman before the start of anti-retroviral therapy or - prophylaxis $[38,39]$ (AIII).
For women who become pregnant during anti-retroviral treatment, German-Austrian guidelines for HIV1therapy in adults recommend resistance testing (AIII) whenever a virological treatment failure is diagnosed.

If at the end of anti-retroviral HIV1-transmission prophylaxis (determined just before - or directly at the time of birth) viral load is detectable in pregnant women, resistance testing should also be performed in order to document the eventual development of resistance under prophylaxis, so that this can be taken into account if the woman requires anti-retroviral therapy at a later timepoint [41] (AIII).

If nevirapine ultra-short prophylaxis (single maternal dose immediately before birth) is given, resistance testing should be carried out 4-6 weeks after the antiretroviral medication was stopped (see points 4 and 5) in order to determine, whether resistance against nevirapine has been induced $[43,44]$ (AIII).

\subsection{INITIAL THERAPEUTIC REGIMEN (see Table 2)}

Apart from the inhibition of viral replication in the mother, a major objective of an optimized initial therapeutic regimen during pregnancy is to combine an effective prophylaxis against HIV1-transmission with the highest possible degree of compatibility for mother and fetus. Restriction of subsequent maternal therapeutic options e.g. because of development of drug resistance should also be avoided.

A standard therapeutic regimen is usually a triple combination including two NRTI + either one (if necessary boosted) protease-inhibitor or + Nevirapin is recommended as an initial maternal therapeutic regimen[29] (AI,II). Efavirenz was excluded due to the reports of cerebral malformations in the newborns of efavirenz-treated pregnant monkeys [45]. Because 3 children with myelomeningoceles and one child with Dandy-Walker-malformation were born to women after treatment with Efavirenz in pregnancy[138], meanwhile Efavirenz was reclassified as FDA pregnancy category D. In addition, nucleoside analogues of particularly high mitochondrial toxicity (i.e. dideoxycytidine (ddC), stavudine (D4T) and didanosine(DDI)) should not be given in combination with one another wherever possible, because of the raised risk of a potentially fatal lactate acidosis in the expectant mother [46] (AIII).

It has to be considered that with the exception of zidovudine, no anti-retroviral drug has been approved for therapy during pregnancy and that the limited experience until now has not permitted any definitive evaluation of the risks and benefits. When choosing anti-retroviral drugs one must also keep in mind that the pharmacokinetics of each drug group (NRTI, NNRTI+PI) can be altered during pregnancy [48, 49, 50]. Therefore during use of PI and NNRTI in pregnancy drug monitoring is compulsory.

\subsection{Management of HIV1-Positive PREgnANT WOMEN WITH HEPATITIS CO-INFECTION}

It is urgently necessary to treat hepatitis-/HIV-co-infected pregnant women in an interdisciplinary setting including an infectious disease specialist. 
Table 2. Comments on the initial anti-retroviral combinations/substances.

\begin{tabular}{|c|c|c|}
\hline \multicolumn{2}{|c|}{ Initial combinations and substances } & \multirow[b]{2}{*}{$\begin{array}{l}\text { Comment } \\
\text { Most clinical experience has been gained with the use of these substances. } \\
\text { One additional rationale for application of zidovudine is the metabolization } \\
\text { of this drug in the placenta which might contribute to the transmission pre- } \\
\text { venting effect }[51,52] \text {. } \\
\text { Some cases of lethal mitochondriopathies were reported in non infected } \\
\text { children after maternal zidovudine/lamivudine-therapy [7, 8]. Data about } \\
\text { long term toxicity especially carcinogenicity/genotoxicity as a matter of in- } \\
\text { corporation of nucleoside analogs into DNA [112] are lacking. In case of } \\
\text { therapeutic failure changed pharmacokinetics of nucleoside analogs because } \\
\text { of pregnancy must to be taken into consideration [113]. }\end{array}$} \\
\hline $\begin{array}{l}\text { Nucleoside analogs } \\
\text { for which most ex- } \\
\text { perience has been } \\
\text { gained }\end{array}$ & $\begin{array}{l}\text { Zidovudine }+ \text { Lamivudine } \\
\text { (also as Combivir }{ }^{\circledR} \text { ) }\end{array}$ & \\
\hline \multirow[t]{3}{*}{ Alternatives } & $\begin{array}{l}\text { Stavudine }+ \text { Lamivudine } \\
\text { Zidovudine+Didanosine } \\
\text { Didanosine + Lamivudine }\end{array}$ & $\begin{array}{l}\text { Less clinical experience in pregnancy. Increased attention relating to poten- } \\
\text { tial side effects. }\end{array}$ \\
\hline & Abacavir & $\begin{array}{l}\text { Use of Abacavir only after testing for HLA-B*5701[136] to avoid } \\
\text { hypersensitivityreaction. So far no increased rate of malformation in } \\
\text { humans [57], but individual reports of malformations [67]. }\end{array}$ \\
\hline & Tenofovir: & $\begin{array}{l}\text { In animal studies, where Tenofovir was applied in higher doses than } \\
\text { usual in humans, reduced bone density and renal damage were } \\
\text { observed [135]. }\end{array}$ \\
\hline NNRTI & Nevirapine: & $\begin{array}{l}\text { Caution: raised liver enzymes, more allergic reactions since pharmacokine- } \\
\text { tics are altered during pregnancy [49]. Increased liver toxicity in pregnancy } \\
\text { especially with CD4-counts }>250 / \mu l \text {. With longer administration enzyme } \\
\text { induction of the cytochrome P450 system and therefore accelerated meta- } \\
\text { bolization of nevirapine not only in the expectant mother but also in the } \\
\text { newborn [53]. A single normal dose applied before birth and to the new- } \\
\text { born is therefore not sufficient for prophy laxis of HIV1-transmission, if } \\
\text { nevirapine has already been given over a longer period during the course of } \\
\text { the pregnancy. }\end{array}$ \\
\hline \multirow[t]{3}{*}{$\begin{array}{l}\text { Protease inhibitors, } \\
\text { for which most } \\
\text { experience has been } \\
\text { accrued }[50] \text { : }\end{array}$} & In common: & $\begin{array}{l}\text { Because of the poor ability of most PIs to cross the placenta (no or poor } \\
\text { data: Fos-Amprenavir [57,113,125], Darunavir [57,113], Tipranavir,) } \\
\text { no therapeutic levels are to be expected in the fetal compartment }[54,55,56] \text {. } \\
\text { As such, no relevant adverse effect frequency is to be expected amongst the } \\
\text { fetuses, but it is still unclear whether therapeutic drug-levels in the fetus are } \\
\text { necessary or helpful to inhibit vertical HIV1-transmission. }\end{array}$ \\
\hline & $\begin{array}{l}\text { Lopinavir + Ritonavir } \\
\left(=\text { Kaletra }{ }^{\circledR} \quad \text { or }\right.\end{array}$ & \\
\hline & $\begin{array}{l}\left.\text { Saquinavir (Fortovase }{ }^{\circledR}\right) \\
+ \text { Ritonavir }\end{array}$ & $\begin{array}{l}\text { Until now rare published studies about the use in pregnancy }[54,57,113] \\
\text { but as yet no incidence for unusual or unexpected adverse effects }[57] \text {. }\end{array}$ \\
\hline \multirow[t]{3}{*}{ Alternatives: } & Nelfinavir & $\begin{array}{l}\text { Up to now most experiences in pregnancy have been accrued for Nelfinavir } \\
{[57,113,126] \text {, but an anti-retroviral therapy with an unboosted PI is no more }} \\
\text { recommended as optimal therapeutic regimen in adults [29]. }\end{array}$ \\
\hline & Ritonavir & $\begin{array}{l}\text { Contraindicated as a mono-PI because of poor compatibility; can be applied } \\
\text { at low doses to boost plasma levels of other PI's. }\end{array}$ \\
\hline & Indinavir + Ritonavir & $\begin{array}{l}\text { High number of tablets, relevant side effects [57]. With Indinavir there is an } \\
\text { increased need for water uptake to prevent the formation of kidney stones } \\
\text { in the mother. }\end{array}$ \\
\hline \multirow[t]{3}{*}{ New substances: } & T-20 (fusion inhibitor) & $\begin{array}{l}\text { Should only be used in heavily pretreated pregnant women as part a of anti- } \\
\text { retroviral salvage therapy based on resistance testing. Because of the high } \\
\text { molecular weight a transplacental passage is not expected and could so far } \\
\text { not proved [121]. Some case reports show no adverse effects }[57,127] \text {. }\end{array}$ \\
\hline & Atazanavir & $\begin{array}{l}\text { Insufficient data for use in pregnancy }[28,57,113] \text {, does not cross placenta } \\
\text { [127]. }\end{array}$ \\
\hline & $\begin{array}{l}\text { Emtricitabin } \\
\text { Fosamprenavir } \\
\text { Tipranavir } \\
\text { Darunavir } \\
\text { Maraviroc } \\
\text { Raltegravir }\end{array}$ & $\begin{array}{l}\text { As yet at the most single case reports [80], no recommendation due to the } \\
\text { risk of malformations possible [57]. }\end{array}$ \\
\hline
\end{tabular}


Table 3.1. Prevention of maternofetal HIV1-infection during a normal course of pregnancy.

\begin{tabular}{|c|c|c|c|c|}
\hline $\begin{array}{l}\text { Status of } \\
\text { expectant } \\
\text { mother: }\end{array}$ & \multicolumn{3}{|c|}{$\begin{array}{l}\text { No ART before pregnancy } \\
\text { Therapy indication according to German-Austrian guidelines for the } \\
\text { therapy of HIV1-infection (30) }\end{array}$} & ART before pregnancy \\
\hline Indication: & $\begin{array}{l}\text { CD4 }>350 / \mu l \\
\text { and HIV1-RNA } \\
<10000 \\
\text { HIVcopies } / \mathrm{ml}\end{array}$ & $\begin{array}{l}\text { CD } 4>350 / \mu l \\
\text { and HIV1-RNA } \\
>10,000 \\
\text { HIVcopies } / \mathrm{ml}\end{array}$ & $\begin{array}{l}\text { A) Clinical disease } \\
\text { ategory } \mathrm{B}+\mathrm{C} \text { or } \\
\text { B) } \mathrm{CD} 4<350 / \mu \mathrm{l}\end{array}$ & $\begin{array}{l}\text { Women is getting pregnant while } \\
\text { receiving an anti-retroviral } \\
\text { combination therapy }\end{array}$ \\
\hline $\begin{array}{l}\text { Maternal } \\
\text { treatment } \\
\text { indication }\end{array}$ & NO & NO & YES & YES \\
\hline $\begin{array}{l}\text { Fetal indi- } \\
\text { cation for } \\
\text { prophylaxis }\end{array}$ & $\begin{array}{l}\text { YES } \\
\text { (prophylaxis with } \\
\text { standard risk) }\end{array}$ & $\begin{array}{l}\text { YES (prophylaxis with } \\
\text { raised maternal } \\
\text { transmission risk) }\end{array}$ & YES & YES \\
\hline \multirow{3}{*}{$\begin{array}{l}\text { Therapy: } \\
1^{\text {st }}-13^{\text {th }} \\
\text { week of } \\
\text { gestation }\end{array}$} & \multicolumn{4}{|c|}{ Resistance testing to exclude primary ZDV resistance } \\
\hline & \multicolumn{4}{|c|}{$\begin{array}{l}\text { Invasive prenatal diagnostics only under anti-retroviral therapy/ prophylaxis } \\
\text { (perform only if absolutely indicated) }\end{array}$} \\
\hline & \multirow{2}{*}{\multicolumn{2}{|c|}{$\begin{array}{c}\text { No ART } \\
\text { At least bimonthly monitoring of CD4 + VL } \\
\text { Start of ART in case of urgent maternal } \\
\text { treatment indication (see above) } \\
\text { Invasive prenatal diagnostics (strictly } \\
\text { indicated !) only under anti-retroviral therapy/ } \\
\text { prophylaxis }\end{array}$}} & $\begin{array}{l}\text { A) Immediate initiation of ART } \\
\text { At least bimonthly monitoring } \\
\text { of CD4 / VL } \\
\text { Switch of ART in case of } \\
\text { therapeutic failure } \\
\text { or } \\
\text { B) Initiation of ART after week } \\
\text { 13, depending on the urgency } \\
\text { of the maternal treatment } \\
\text { indication (see below). } \\
\text { At least bimonthly monitoring } \\
\text { of CD4 +VL } \\
\text { Start of the ART before week } \\
13 \text { in case of urgent maternal } \\
\text { treatment indication }\end{array}$ & $\begin{array}{l}\text { A) Interruption of ART if clinical, } \\
\text { immunological and virological } \\
\text { status of the mother allows } \\
\text { (CAVE: Interruption of NNRTI } \\
\text { with long half-life !!!) } \\
\text { At least bimonthly monitoring of } \\
\text { CD4 and VL } \\
\text { Immediate restart of ART in } \\
\text { case of urgent maternal } \\
\text { treatment indication or } \\
\text { B) Otherwise continuation of } \\
\text { ART, if necessary substitution of } \\
\text { efavirenz; substitution of } \\
\text { stavudine + didanosine if given } \\
\text { in combination } \\
\text { At least bimonthly monitoring of } \\
\text { CD4 and VL }\end{array}$ \\
\hline $\begin{array}{l}\text { Therapy: } \\
14^{\text {th }}-30^{\text {th }} \\
\text { week of } \\
\text { gestation }\end{array}$ & & & \multirow{2}{*}{\multicolumn{2}{|c|}{$\begin{array}{l}\text { Beginning/ restart of ART e.g. with ZDV }+3 \mathrm{TC} / \mathrm{ddI}+ \\
\text { PI / NVP or premedication, } \\
\text { if possible without EFV or } \mathrm{d} 4 \mathrm{~T}+\mathrm{ddI} \\
\text { At least bimonthly monitoring of CD4 and VL, }\end{array}$}} \\
\hline $\begin{array}{l}\text { Therapy: } \\
\left(28^{\text {th }}\right) / 30^{\text {th }} \\
37^{\text {th }}(+0) / \\
37^{\text {th }}(+6) \\
\text { week of } \\
\text { gestation }\end{array}$ & $\begin{array}{l}\text { A) ZDV (AI) } \\
2 \times 250 \mathrm{mg} / \mathrm{d} \text { p.o. } \\
\text { B) HAART (BI) e.g. } \\
\text { with ZDV + 3TC + } \\
\text { PI/NVP; } \\
\text { if possible without } \\
\text { EFV or d4T+ddI }\end{array}$ & $\begin{array}{l}\text { HAART e.g. with } \\
\text { ZDV + 3TC }+ \\
\text { PI / NVP } \\
\text { if possible without EFV } \\
\text { or d4T+ddI }\end{array}$ & & \\
\hline $\begin{array}{l}37 \text { th }(+0)- \\
37 \text { th }(+6) \\
\text { week of } \\
\text { gestation }\end{array}$ & \multicolumn{4}{|c|}{ 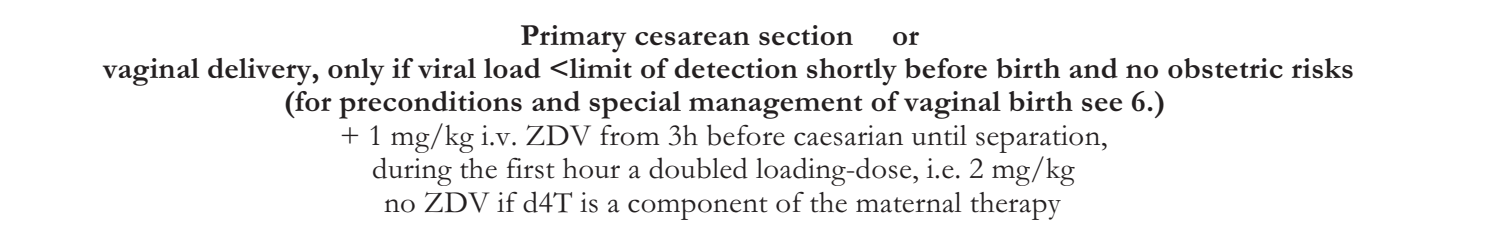 } \\
\hline $\begin{array}{l}\text { Newborn } \\
\text { with a com- } \\
\text { plication- } \\
\text { free birth } \\
\text { process }\end{array}$ & \multicolumn{4}{|c|}{$\begin{array}{l}\text { A: ZDV } 4 \text { × } 2 \mathrm{mg} / \mathrm{kg} / \mathrm{d} \text { p.o. for } 2-4 \text { weeks or } \\
\text { B: ZDV } 4 \text { × } 1,5 \mathrm{mg} / \mathrm{kg} / \mathrm{d} \text { i.v. for } 10 \text { days } \\
\text { Refraining from breast-feeding }\end{array}$} \\
\hline
\end{tabular}

ZDV, zidovudine; ART, anti-retroviral combination therapy with usually three medications: two nucleosidal reverse transcriptase inhibitors + a protease inhibitor (PI) or nevirapine; 3TC, lamivudine; ddI, didanosine; d4T, stavudine; NVP, nevirapine; EFV, efavirenz; VL, virus load 


\subsubsection{Management of HIV1-positive pregnant} women with Hepatitis B virus (HBV) co-infection

According to the German-Austrian guidelines for the therapy of HIV1-infection in adults (30) an anti-retroviral three drug regimen including Tenofovir plus 3TC or Tenofovir plus FTC, which all three have for antiviral activity for hepatitisB, is also recommended for HIV-positive pregnant women with Hepatitis B co-infection. Because of alarming study results in pregnant animals [135, see also 2.3] Tenofovir should be used with caution in pregnancy. In the special case of HBV co-infection in HIV-positive pregnant women the riskbenefit analysis will more often result in the use of Tenofovir, because of the advantage in therapy of Hepatitis $B$.

Interferon-alpha and pegylated interferon-alpha are not recommended during pregnancy.

After starting anti-retroviral therapy in pregnancy a $\mathrm{HIV} / \mathrm{HBV}$ co-infected pregnant women should be monitored at close intervals. Not later than two weeks after start of therapy the first laboratory control has to be performed. Thereafter monthly controls are adequate.

If the anti-retroviral therapy will be ceased after pregnancy (no maternal - but fetal indication for therapy) severe flare-up's of HBV disease should be taken into account and the close laboratory controls must be continued after birth. In case of an indication for therapy of hepatitis B-infection only, after birth a change in therapy to drugs against HBV with no anti-HIV activity is possible.

All infants born to HBV-infected women should receive hepatitis B immune globulin (HBIG) and initiate the three dose hepatitis $B$ vaccination series within 12 hours.

\subsubsection{Management of HIV1-positive pregnant} women with Hepatitis $\mathrm{C}$ virus (HCV) co-infection

Because maternal HCV-infection increases the risk of vertical HIV-transmission, an effective anti-retroviral combination therapy is recommended for HCV-/HIVco-infected pregnant women.

An effective anti-retroviral HIV-therapy during pregnancy also reduces mother-to-child- transmission of $\mathrm{HCV}$.

In HIV/HCV co-infected pregnant women laboratory examination should be performed two weeks following initiation of anti-retroviral therapy and then at least monthly.

Pegylated interferon-alpha is not recommended and ribavirin is contraindicated during pregnancy because of teratogenicity (FDA category X).

Decisions concerning the mode of delivery in $\mathrm{HIV} / \mathrm{HCV}$ co-infected pregnant women should be based on considerations related to HIV infection alone.

\subsection{INTERRUPTION OF ANTI-RETROVIRAL THERAPY DURING THE 1ST TRIMESTER OF THE PREGNANCY}

The decision to interrupt maternal anti-retroviral therapy in the 1 st trimester of pregnancy depends on the individual clinical, immunological and virological status of the pregnant woman as well as the anti-retroviral treatment case history. If the patient was clinically symptomatic before the start of anti-retroviral therapy, or if immunological and/or virological parameters showed an advanced state of immune deficiency and/or a very high risk for rapid disease progression, interruption of therapy is fraught with greater risks for the pregnant women than it is for a clinically asymptomatic woman, whose laboratory parameters might justify the start of an anti-retroviral therapy, but whose clinical status is stable and whose laboratory parameters are no cause for major immediate concern.

It must necessarily mentioned, that up to now all randomized trials of structured treatment interruption/STI versus continuous therapy, especially the SMART-study [139] (interruption of therapy with CD4 $>350 / \mu \mathrm{l}$ and restart of therapy with CD $4<250 / \mu \mathrm{l}$ versus continuous therapy), showed a more worse outcome in the STI-group according to cardiovascular disease, opportunistic infections, AIDS, death etc..

Vertical HIV1-Transmission occurs very rarely during the first 12 weeks, and is most common at the end of pregnancy and during birth. Therefore an effective HIV1-transmission prophylaxis does not require antiretroviral therapy during the entire pregnancy. Since currently adverse side effects (especially during the organogenesis) can not be excluded, particularly with application during the first trimester, an at most 3 month interruption of maternal anti-retroviral therapy should be taken into consideration $[133,134]$. The decision to interrupt anti-retroviral therapy in the first trimester of pregnancy should be made individually and according to individual risk profiles with the informed consent of the mother. If therapy is interrupted, monitoring intervals should be short (at least monthly measurement of t-helper cell number and the virus load) (AII,III).

Up to now, no results of controlled trials have been published regarding the risks associated with interruption of anti-retroviral therapy during pregnancy, and inadequate data exist to allow any estimation of the risk that anti-retroviral combination therapy during the 1 st pregnancy trimester entails for the child $[12,57]$.

From an embryo-toxicological standpoint, no drugs with unclear human teratogenic potential should be applied in the first trimester until the 11th completed week of gestation +0 , (after the last regular menstruation) due to their potential effects on organogenesis $[58,59,60]$.

If a decision is made in favor of therapy interruption, all anti-retroviral medications should be ceased. In regimes consisting of 3 NRTI or 2 NRTI +PI the simultaneous interruption of all drugs can be managed without problems.

In contrast, because of a possible long half-life up to 3-4 weeks of NNRTI [141] with a high interindividual variability, simultaneous interruption of an antiretroviral combination therapy with 2 NRTI+1NNRTI (such as efavirenz and nevirapine) results in an temporary monotherapy with a high risk of development of NNRTI-resistance. At present the most safe management of this problem in non-pregnant individuals is to replace the NNRTI by a (boosted) PI and cease this 
Table 3.2. Prevention of vertical HIV1-transmission in case of pregnancy - and birth complications.

\begin{tabular}{|c|c|c|c|c|c|}
\hline $\begin{array}{l}\text { Pregnancy } \\
\text { complication: }\end{array}$ & $\begin{array}{l}\text { Complication-free } \\
\text { (multiple) pregnancy } \\
\text { and viral load shortly } \\
\text { before birth }<3000 \\
\text { HIV copies } / \mathrm{ml}\end{array}$ & $\begin{array}{c}\text { Viral load } \\
\text { shortly before } \\
\text { birth } \\
3000-10000 \\
\text { HIV copies } / \mathrm{ml}\end{array}$ & $\begin{array}{l}\text { - Premature labor } \\
\text { - premature birth in } \\
\geq 33^{\text {rd }}(+0)-36^{\text {th }} \\
(+6) \mathrm{GW}\end{array}$ & $\begin{array}{l}- \text { AIS/amnionitis } \\
\text { - premature birth } \\
<33^{\text {rd }}(+0) \text { GW }\end{array}$ & $\begin{array}{l}\text { Viral load increase at } \\
\text { the end of a pregnancy } \\
>10000 \mathrm{HIV} \text { copies } / \mathrm{ml} \\
\text { e.g. because of lacking } \\
\text { prepartal prophylaxis }\end{array}$ \\
\hline $\begin{array}{l}\text { HIV1-trans- } \\
\text { mission risk }\end{array}$ & Normal & \multicolumn{2}{|c|}{ Raised } & \multicolumn{2}{|c|}{ Very high } \\
\hline $\begin{array}{l}\text { Measures in } \\
\text { the } 24^{\text {th }}(+0)- \\
37^{\text {th }}(+0-6) \\
\text { week of } \\
\text { gestation }\end{array}$ & $\begin{array}{l}\text { Mutliple pregnancy: } \\
\text { Prophylaxis onset } \\
\text { brought forward with } \\
\text { ZDV or ART after GW } \\
29(+0) \text { because of the } \\
\text { risk of premature birth }\end{array}$ & & $\begin{array}{l}\text { - Tocolysis, } \\
\text { - if necessary antibiotic } \$ \\
\text { - RDS-prophylaxis } \\
\text { - HAART e.g.:ZDV+ } \\
\text { 3TC + PI/NVP } \\
\text { (if possible no EFV or } \\
\text { d4T+ddI) }\end{array}$ & & \\
\hline \multirow[t]{2}{*}{$\begin{array}{l}\text { Birth: } \\
37^{\text {th }}(+0)-37^{\text {th }} \\
(+6) \text { week of } \\
\text { gestation }\end{array}$} & \multirow{2}{*}{$\begin{array}{l}\text { (Elective) Primary } \\
\text { cesarean section/CS } \\
\text { or vaginal delivery } \\
\text { (the latter only if viral } \\
\text { load <limit of } \\
\text { detection shortly } \\
\text { before birth and no } \\
\text { obstetric risks / for } \\
\text { management of } \\
\text { vaginal birth see } 6 . \text { ) } \\
+1 \mathrm{mg} / \mathrm{kg} \text { i.v. ZDV } \\
\text { starting } 3 \text { h before } \\
\text { cesarean until birth, } \\
\text { during the first hour a } \\
\text { doubled loading-dose, } \\
\text { i.e. } 2 \mathrm{mg} / \mathrm{kg}\end{array}$} & \multirow{2}{*}{\multicolumn{2}{|c|}{ Only (Elective) CS !! }} & $\begin{array}{l}\text { If still possible (de- } \\
\text { cision dependent of } \\
\text { obstetrical situation) } \\
\text { cesarean within } 4 \mathrm{~h} \\
\text { after rupture of } \\
\text { membranes }\end{array}$ & Elective CS \\
\hline & & & & \multicolumn{2}{|c|}{$\begin{array}{l}+1 \mathrm{mg} / \mathrm{kg} \text { i.v. ZDV from } 3 \mathrm{~h} \text { before cesarean } \\
\text { until birth, during the first hour a doubled } \\
\text { loading-dose, i.e. } 2 \mathrm{mg} / \mathrm{kg} \\
\text { Prepartal } 1 \mathrm{x} 200 \mathrm{mg} \mathrm{NVP} \text { in addition to the } \\
\text { ongoing ZDV prophylaxis or ART } \\
\text { ZDV prophylaxis or ART }\end{array}$} \\
\hline $\begin{array}{l}\text { Postnatal } \\
\text { prophylaxis } \\
\text { of the } \\
\text { newborn } \\
(108) \text { : }\end{array}$ & $\begin{array}{l}4 \text { weeks: } \\
\text { Dosing with } \\
\text { newborns: } \\
\text { ZDV } 4 \text { x } 2 \mathrm{mg} / \mathrm{kg} / \mathrm{d} \text { p.o. } \\
\text { Refraining from } \\
\text { breast-feeding }\end{array}$ & \multicolumn{2}{|c|}{ 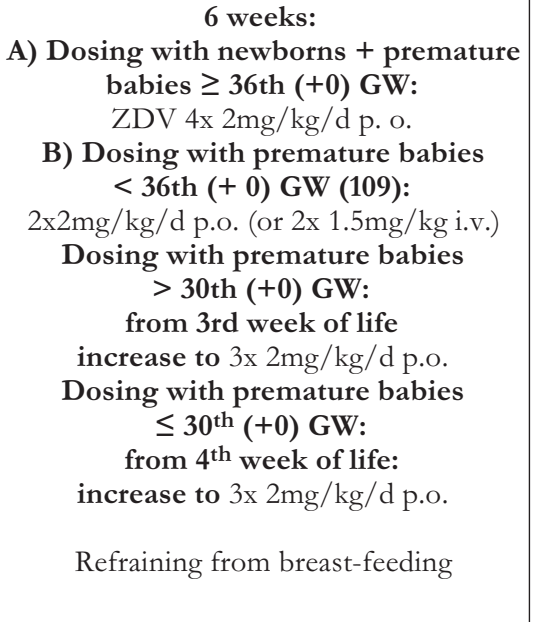 } & \multicolumn{2}{|c|}{ 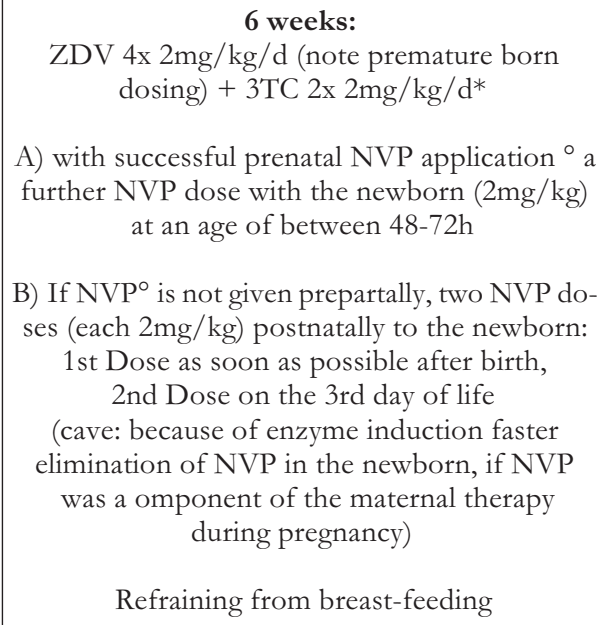 } \\
\hline $\begin{array}{l}\text { Birth com- } \\
\text { plications: }\end{array}$ & \multicolumn{5}{|c|}{$\begin{array}{l}\text { - Incision injury to the child } \\
\text { - Oral intake of bloody amniotic fluid into gastrointestinal or } \\
\text { respiratory tract of the newborn }\end{array}$} \\
\hline $\begin{array}{l}\text { HIV1-trans- } \\
\text { mission risk }\end{array}$ & \multicolumn{5}{|c|}{ Very high } \\
\hline $\begin{array}{l}\text { Postnatal } \\
\text { measures in } \\
\text { the newborn: }\end{array}$ & \multicolumn{5}{|c|}{$\begin{array}{l}\text { 6 weeks: } \\
\mathrm{ZDV} 4 \times 2 \mathrm{mg} / \mathrm{kg} / \mathrm{d} \text { (check premature born dosing wherever necessary) }+3 \mathrm{TC} 2 \mathrm{x} 2 \mathrm{mg} / \mathrm{kg} / \mathrm{d}^{*}\end{array}$} \\
\hline
\end{tabular}

* Beware: Presently only a few clinical results have been published regarding the application and dosing of lamivudine with (extreme) premature infants.

- Beware: if the HIV1-positive expectant mother has been treated for a longer period of time with nevirapine during pregnancy, an enzyme induction may occur that may lead to a more rapid breakdown of nevirapine in the newborn.

ZDV, zidovudine; ART, anti-retroviral combination therapy usually with three medications: two nucleoside reverse transcriptase inhibitors + one protease inhibitor (PI) or nevirapine; 3TC, lamivudine; ddI, didanosine; d4T, stavudine; NVP, nevirapine; EFV, efavirenz; AIS, amnion infection syndrome 
new anti-retroviral treatment after 4 weeks. As an alternative the 2NRTI are continued over 4 weeks after stopping NNRTI (if possible under monitoring the NNRTI-level via therapeutic drug monitoring) [29, 122]. Because a pregnancy is usually observed not before some weeks after conception, an additional 4 weeks lasting procedure to interrupt a regimen with 2NRTI+NNRTI interferes with the avoidance of these drugs during organogenesis. Therefore a prompt interruption of NNRTI-containing regimens can hardly be arranged in the first 6-8 weeks of gestation (where most organs develop) and therefore can not be recommended. Nevertheless an interruption of a combination with NNRTI in the remaining weeks should be guided by an HIV-experienced infectious disease specialist to minimize the development of drug resistance.

The anti-retroviral treatment should not be resumed before the 13 th $(+0)$ week of pregnancy in order to take into account the uncertainties in the exact time of conception.

If a woman under anti-retroviral therapy has planned for a child, a pregnancy test (HCG) should be undertaken very early on. The pregnancy test becomes positive 6-8 days after conception, thus a decision to interrupt anti-retroviral therapy can be made accurately in time. On the other hand because the time until conception cannot be calculated and can last very long an anti-retroviral therapy should never be stopped before conception even when the pregnancy is planned.

If a HIV1-positive women plans to get pregnant, if possible no Efavirenz containing ART should be started or Efavirenz containing regimes should be changed to regimens with other components (for example boosted PI, Nevirapine) in time.

After interruption in the first trimenon therapy with the same drugs can be restarted (exceptions: efavirenz, combination of stavudine + didanosine, provided that therapeutic alternatives are available) $[45,46]$, since resistance development is not to be expected [32, 33] (AII,III).

These recommendations also apply if pregnancy is first diagnosed during the course of the 1 st trimester.

\section{HIV1-TRANSMISSION PROPHYLAXIS WITH STANDARD RISK PROFILE (SEE TABLE 3.1)}

Prophylactic scheme (= no maternal treatment indication, criteria see table $3.1 ! ! ! !)$ :

\section{1a) Viral load in the expectant mother $<10,000$} genome copies $/ \mathrm{ml}$ :

In this situation two alternative regimens can be used:

I. Zidovudine application from the completed 30th (or 28th) (+0) GW at an oral dose of $2 \times 250 \mathrm{mg}$.

II. Temporary anti-retroviral combination therapy with 3 drugs (HAART, but if possible no Efavirenz) from week of gestation $30+0(28+0)$ until immediately after birth

Comments to oppurtunity I:

Provided that there is no primary resistance to zidovu- dine, a reduction of viral load at birth can be achieved under a zidovudine-monoprophylaxis from a low initial virus load. This suffices - particularly in combination with a planned cesarean birth - for minimizing the risk of transmission to the child $[5,71,72,124,131$, 132]. The advantage in comparison with HAART is the lower risk of prophylaxis-associated toxicity for mother and child. Because of the short duration of this monoprophylaxis and of the comparatively high resistance barrier of zidovudine the risk of developing a resistance against zidovudine should be very low [68, 115]. In comparison to HAART the risk in monoprophylaxis (provided a good adherence to both regimens) is higher that viral load is not reduced sufficiently until birth.

\section{Comments to oppurtunity II:}

Under a temporary standard anti-retroviral therapy (HAART) from week of gestation $30+0(28+0)$ until immediately after birth the low viral load can be decreased under limit of detection at birth with a high probability [5, 71, 130, 131, 132]. Because of the long half life (which can induce resistance during a cessation after birth) and increased toxicity in patients with CD4-cells higher than $250 / \mu \mathrm{l}$, this prophylactic HAART should not contain Nevirapine. Ideal for prophylaxis are regimens with a (boosted) PI [29]. Provided a good adherence the risk of induction of a drug resistance is lower than in a monoprophylaxis with zidovudine. Disadvantage of a prophylaxis with HAART is the higher drug burden for mother and child, which can lead to more adverse effects and toxicities than in a monoprophylaxis. These complications can reduce adherence and then result in development of drug resistance [114]. On the other hand changed pharmacokinetics of anti-retrovirals in pregnancy (published for Indinavir; for many other anti-retroviral drugs no pharmacokinetic data in pregnancy exist) can induce drug resistance $[41,61,62,63,64,65,66,68,69,70,113]$.

In the decision to use a monoprophylaxis with zidovudine or HAART in pregnant women with a viral load $<10,000$ genome copies $/ \mathrm{ml}$ also the elevated rate of prematurity under HAART, which increases vertical transmission of HIV, must be taken into account $[101,115,116]$.

3.1b) viral load in the expectant mother $>10,000 \mathrm{HIV}$ genome copies / $\mathrm{ml}$ :

The risk of vertical transmission is directly proportional to the viral load in the pregnant women. If there is not yet a distinct maternal indication for treatment (CD4 cell count $>350 / \mu \mathrm{l}$ ), but the viral load is higher than 10,000 virus copies $/ \mathrm{ml}$, a temporary anti-retroviral standard combination prophylaxis (without efavirenz !) is recommended from GW $30+0$ (or $28+0$ ) to immediately after delivery, since a zidovudine monoprophylaxis is not able to reduce the viral load with adequate certainty (raised risk of transmission with VL > 10,000 [5, 62, 71, 72, 73, 74] (AI,II).

In case of a very high viral load (>100 000HIVcopies $/ \mathrm{ml}$ ) a start of anti-retroviral prohylaxis can considered in GW 28+0. The early start of prophylaxis allows for controls of success of anti-retrovirals at an early stage (e.g. in GW $32+0$ ). If a change of anti- 
retroviral prophylaxis is necessary at that timepoint, for the new regimen there is enough time until birth to suppress viral load as much as possible.

3.2 Primary cesarean section, available between 37 $(+0)$ to $37(+6)$ gestational week utilizing an operation technique which avoids excessive bleeding, performed rapidly by the most experienced obstetrician [75,76]. The benefit of the elective cesarean section for transmission prophylaxis in patients under an anti-retroviral combination therapy or prophylaxis with a low viral load in the plasma, is not evidenced and is still a matter of dispute (see point 6 for a detailed discussion of the mode of birth) (AI,II).

3.3 Pre- and intra-operative intravenous zidovudine application starting 3 hours before cesarean section (2 $\mathrm{mg} / \mathrm{kg}$ as a loading-dose for 1 hour followed by 1 $\mathrm{mg} / \mathrm{kg}$ until the delivery of the child according to the original ACTG 076 protocol), even if zidovudine is not a component of the maternal therapy/ prophylaxis during the pregnancy [77] (AI).

3.4 Postnatal zidovudine application for the child over 2-4 weeks orally ( $2 \mathrm{mg} / \mathrm{kg}$ every 6 hours) or 10 days i.v. (1.5 mg/kg every 6 hours) [78] (AI).

Since a higher prevalence of zidovudine-resistant HIV1-strains can be expected in the future [40], the presence of wild-type HIV1 should be confirmed genotypically in the expectant mothers before zidovudine is applied (exclusion of genotypic resistance).

\section{RISK-ADAPTED TRANSMISSION PROPHYLAXIS} (SEE TABLE 3.2)

For birth-related HIV1-transmission risks, HIV1transmission prophylaxis should be escalated in a riskadapted manner.

4.1 Multiple pregnancy, premature labor and premature infants $33 \mathrm{rd}(+0)-36 \mathrm{th}(+6) \mathrm{GW}$ and maternal viral load 3 000- $10000 \mathrm{HIV-copies/ml} \mathrm{before} \mathrm{birth}$

Because of the increased risk of premature birth in multiple pregnancies, prophylactic zidovudine application should already be started from the 29th $(+0)$ week of gestation (AIII).

In case of premature labor, anti-retroviral combination prophylaxis should be started immediately (with e.g. zidovudine + lamivudine + PI), if the pregnant women is not yet receiving a combination therapy, if a cesarean birth is not indicated because of immaturity of the baby and if labor can still be stopped (AIII).

If a premature birth is unavoidable, the procedure described in 4.2 should be followed.

If e.g. because of a premature delivery etc. the viral load of the mother is between $3000-10000 \mathrm{HIV}$ copies $/ \mathrm{ml}$ before birth, the postnatal prophylaxis should be prolonged according to the ACTG 076study protocol, where zidovudine is applied over 6 weeks orally $[14,63]$. The newborn should be closely monitored during this prolonged prophylaxis. If problems such as anemia, neutropenia or lactate acidosis occur, benefits and risks of continuing the prophylaxis should be carefully weighed, and in doubt prophylaxis should be discontinued (A/III).

4.2 Amnion infection syndrome/amnionitis, premature rupture of membranes $>4 \mathrm{~h}$, premature birth $<33$ rd $(+0)$ GW and viral load increase at the end of pregnancy $>10000 \mathrm{HIV}$ copies $/ \mathrm{ml}$

In these obstetric emergency situations the transmission risk is greatly increased [3, 5, 15, 16, 72, 79, 132]. The prepartal part of the prophylaxis should (as long as a standard combination therapy/prophylaxis is not already being given) be intensified by an (additional) dose of nevirapine as long as this is still possible [83].

Postnatally, transmission prophylaxis can also be escalated in the newborn through application of nevirapine in addition to a combination prophylaxis with zidovudine + lamivudine $[82,83,84]$. In this case one dose of nevirapine should be given to the newborn after $72 \mathrm{~h}$ if the mother has already received one dose prepartally (minimum 2 hours before birth). Two doses should be given if the mother did not receive a prepartal dose or if less than two hours have elapsed between nevirapine application to the mother and birth [56, 81, 83]. If two doses are given, the first should be given immediately -and the second within $72 \mathrm{~h}$ after birth (AI,III).

Under nevirapine ultrashort monoprophylaxis (one dose of nevirapnie shortly before birth) there is a considerable risk of resistance development in the mother $(>20 \%)$. To reduce this risk either continuous combination therapy (in the case of treatment indications for the mother) or transient combination therapy - e.g. additional 2 NRTI's over a period of 1 week after oral nevirapine should be considered as a possible protective measure against resistance development (see also the strategies described under 2.5/therapy interruption). So far no evidence base for this strategy.

2-4 weeks after termination of transient combination therapy or ultrashort monoprophylaxis it should be evaluated, whether resistance has been induced by resistance testing.

If the HIV1-positive expectant mother was treated with nevirapine for a longer period during the pregnancy, an enzyme induction might result in the newborn so that a more rapid breakdown of nevirapine occurs [53]. For this reason, with longer nevirapine therapy of expectant mothers during pregnancy, the drug must be applied at higher doses to the newborns (4 mg/kg).

The preferred mode of delivery is immediate cesarean section if the rupture of membranes does not already date back longer than 4 hours. For intervals $>4$ h after (premature) rupture of membranes, no advantage of cesarean section regarding transmission risks can be expected [85]. However, the decision to implement this must be based on obstetric considerations.

Rupture of membranes between the 24th and 28th gestational weeks represents a particularly problematic special case. Steroid induced pulmonary maturation in the unborn is not effective before 24 hours after application and therefore contradicts measures required for preventing HIV1-transmission. In this case the high risk of permanent damage to the child due to lacking 
pulmonary maturation and the increased HIV1-transmission rate must be carefully weighed up.

\subsection{INCISION INJURY TO THE CHILD/ ASPIRATION AND/OR INGESTION OF BLOODY AMNIOTIC FLUID}

With an incision injury to the child during caesarian section, or if bloody amniotic fluid can be aspirated from the stomach and/or the lungs, a percutaneous inoculation or a mucosal exposure to virus-containing body fluids must be assumed [23]. This justifies an intensification of the usual standard pediatric prophylaxis to a combination prophylaxis consisting of two NRTI-s consistent with post-exposure prophylaxis recommendations for adults [86] (AIII). An extended application of nevirapine (exceeding the ultra-short prophylaxis) for post-exposure prophylaxis can not be recommended at this time because of the lack of data regarding pharmacokinetics and safety.

Because of the lack of experience and formal approval of protease-inhibitors and NNRTIs for the therapy of newborns, and because of the dearth of comparative studies on the efficacy of double NRTI and triple drug post-exposure prophylaxis regimens, the recommendations for treatment escalation are limited to measures that have been proven effective and tolerable within the context of mother-to-child transmission prophylaxis. For these reasons the postexpositional prophylaxis of newborn with high risk of HIVtransmission should be limited to two NRTI's combined with one or two doses Nevirapine.

\section{Procedures WITH INCOMPLETE TRANSMISSION PROPHYLAXIS}

\subsection{WITH VERIFIED HIV1-INFECTION}

If despite of a known HIV1-infection no transmission prophylaxis has been carried out until the time of birth, this should be done at the latest during delivery and postnatally. A benefit for the newborn can even be expected with incomplete transmission prophylaxis $[63,64,87,88,89]$. A combination of a nevirapine ultrashort prophylaxis (one dose prepartally for the mother, one dose postnatally for the newborn or 2 doses postnatally) with a six-week zidovudine or zidovudine + lamivudine application for the newborn is then recommended (AI).

According to data from the HIVNET 012 study, a single dose of nevirapine shortly before birth combined with a single dose given to the newborn within 72 hours of birth is more effective in preventing vertical transmission than the immediate pre- and intrapartal administration of zidovudine combined with a week long postnatal administration of zidovudine to the newborn [87]. (Measures of maternal short time nevirapin prophxlaxis see also 4.2)

Zidovudine prophylaxis started within 48 hours after birth according to the ACTG 076 protocol (application over 6 weeks) can still lower the HIV1-transmission rate. In a retrospective US study a transmission rate of $9.3 \%$ has been reported with initiation of zidovudine therapy in the first 48 hours after vaginal delivery, as compared to a rate of $18.4 \%$ for a later on- set of therapy (>48 h). Without any therapy, $26.6 \%$ of the children became infected[64].

\subsection{SitUATION WITH AN UNCLEAR HIV1-INFECTION STATUS}

If a patient presents late in her third trimester without HIV-Test and sufficient time remains to perform a screening test (and if necessary a confirmatory test), this should be offered without delay, so that intrapartal and postpartal transmission prophylaxis can be carried out whenever the test proves positive [64].

The HIV-antibody test should be accompanied by competent personal counseling, provided if necessary by an appropriate institution [1,2]. The refusal to undergo HIV-antibody testing must be respected.

In cases when the HIV status of the pregnant women is unknown and there is no time to carry out regular testing and counseling, an HIV-rapid test should be offered and prophylactic measures can be instituted with positive rapid test results. During counseling the pregnant women about HIV-rapid tests, it should considered, that in spite of accurateness of these tests (sensitivity and specificity of HIV-rapid tests achieve results of $>99,5 \%$ ) the probability, that a positive HIV-rapid test is positive in confirmatory tests can be less than $50 \%$ in the view of the low prevalence of unknown HIV1-infections in pregnant women (estimated about 50-100 cases per 200.000300.000 untested pregnant women until 2007). Therefore every positive HIV-rapid test must be confirmed by HIV-Elisa or HIV-Westernblot. If the confirmation fails, all measures to avoid HIV1-transmission must be ceased immediately.

An opportunity to further increase the specificity arises from controlling a positive rapid test finding with a second rapid test procedure. If the second test reports a negative finding, the probability is high that the first test result was false positive.

\section{MODE OF DELIVERY}

Studies, analyzing HIV1-positive pregnant women and their children before the beginning of the HAARTera, showed a significant reduction of mother-tochild-transmission of HIV1 by a primary cesarean section. Delivery by elective cesarean section (before the onset of labor) resulted in a reduction of the vertical transmission risk by approximately $50 \%$, i.e. in a $8.2 \%$ vs. $16.8 \%$ risk associated with vaginal birth[76]. Elective Cesarean section should therefore represent an essential component of every prophylactic HIV1-transmission regimen (AI,II). On the other hand some studies which compared healthy pregnant women with HIV1-infected pregnant women showed a higher rate of complications as cause of cesarean section (e.g. higher rates of fever, hematoma and wound infection [117, 118, 139]) in HIV1-positve women. In contrast other studies failed to prove these disadvantages of cesarean section $[97,98,99,100]$.

According to recent examinations the protective effect of cesarean section in HIV1-positive women, who were treated with HAART in pregnancy and whose HIV-viral load was under limit of detection at the end 
of pregnancy, seems to be minimal $[132,137,138])$. Hence a vaginal delivery is arguable under these optimal conditions (HAART in pregnancy, HIV-viral load in pregnancy especially shortly before birth under limit of detection), when it is the request of the pregnant women and no obstetric risks argue against it.

Practical procedure in the delivery room:

Preoperative/ intra-operative i.v. zidovudine therapy of the mother at a dose of $1 \mathrm{mg} / \mathrm{kg} / \mathrm{h}$ after a loading-dose of $2 \mathrm{mg} / \mathrm{kg}$ over 1 hour until delivery still represents a prophylactic measure independently of mode of delivery (AI, AII).

a) The elective, primary cesarian section should be carried out by the most experienced obstetrician available utilizing an operation technique which avoids excessive bleeding, performed between $37(+0)$ to $37(+6)$ gestational week on a labor-free uterus under i.v. application of zidovudine. Because of lower maternal complications (pneumonia/fever) and the possible early bonding in delivery room a local anesthetic procedure (e.g. spinal anesthesia) is preferably recommended [97].

b) To keep the risk of vertical HIV1-transmission as low as possible during an intended vaginal delivery some special features have to be considered:

Invasive monitoring of the newborn (sampling of microbloodprobes from fetal scalp, scalp electrodes etc.) should not be used. A maybe necessary amniotomy has be performed as late as possible. An operative vaginal delivery should be avoided. Especially in case of protracted labour, abnormal fetal heart rate or suspicion of AIS/amnionitis etc. the indication/decision for a (secondary) cesarean section should be taken into account generously and earlier as usual.

It should be noted that an increased rate of premature birth has been documented on several studies in mothers treated with an anti-retroviral combination therapy [101]. However, two large American studies [5, 36] failed to find an increased rate of premature birth under HAART. Considering these contradictory findings, in the last trimester special attention must be paid towards women with anti-retroviral combination therapy or other risk factors for premature birth so that a premature birth or other emergency mode of birth under unfavorable conditions can be avoided. This is warranted by frequent antepartum controls in the third trimester and, under certain conditions, early hospitalization.

It is urgently recommended that an HIV post-exposure prophylactic emergency set be kept in stock by the hospital and that all medical personnel involved is informed about an emergency plan including indications and procedures related to HIV post-exposure prophylaxis (PEP) after occupational HIV exposure (e.g. following needle prick or knife injuries to the operating surgeon). For actual German-Austrian PEP guidelines see www.daignet.de under HIV-therapy.

\section{CARE OF THE NEWBORN IN THE DELIVERY ROOM}

Amniotic fluid can be contaminated with HIV1 by the opening of the amniotic sac during both a spontaneous delivery and a cesarean section. With a vaginal delivery there is also the possibility that virus-contain- ing vaginal secretions or maternal blood gain access to the body openings of a child [23, 93]. Unlike adults, the mucous membranes of the respiratory and gastrointestinal tracts do not represent barriers to HIV1 in the newborn, and the still anacidic stomach can fail to inactivate the virus. Higher transmission rates from HIV1-infected mothers to breast-fed (as opposed to bottle-fed) children confirm that the oral uptake of virus-containing fluids plays a considerable role in vertical transmission [102].

Practical procedure in the delivery room:

The use of sterile gloves is recommended for initial treatment. Before suction of the mouth, the oral cavity and the nostrils should be cleaned of any potentially HIV1-contaminated amniotic fluid using sterile swabs soaked in $0.9 \%$ physiological saline. After stabilization of vital functions, all body openings (ears, eyes, anus and genitals) should be cleaned in the same way.

Before the final severance of the umbilical cord, gloves must be changed in order to avoid any HIV1contamination of the umbilical stump (AIII).

\section{PostnATAL TRANSMISSION PROPHYLAXIS IN CASE OF STANDARD RISK}

The recommendation of oral zidovudine application over 6 weeks to the child at a dose of $2 \mathrm{mg} / \mathrm{kg}$ every 6 hours results from the findings of the ACTG 076 study [14]. After oral zidovudine application during pregnancy, intravenous zidovudine infusion during birth, and elective cesarean section, this represents the fourth component of HIV1-transmission prophylaxis. A deescalation of the six-week postnatal component (according to the ACTG-076 protocol) of the transmission prophylaxis is justified by the results of a study carried out in Thailand involving a shortened zidovudine regimen and considering experience gained in Germany until now. The Thai study showed that the six week therapy produced an additional benefit as compared to a three day postnatal zidovudine dosing when the duration of prepartal prophylaxis was very short (from the 36th week of gestation with spontaneous delivery as the predominant mode of birth) [63]. In Berlin, satisfactory results (no transmissions) have been achieved (involving a small number of cases, $\mathrm{n}=57$ [78]) with an i.v. dosing of $1.3 \mathrm{mg} / \mathrm{kg}$ every 6 hours over 10 days if the prepartal prophylaxis was started in the $32 \mathrm{nd}$ week of gestation. The majority of experts conclude from this that postnatal zidovudine should be given to the child, although they consider a reduction of the duration of postnatal zidovudine transmission prophylaxis to 2 to 4 weeks ( $2 \mathrm{mg} / \mathrm{kg}$ orally every 6 hours) as usually sufficient (AI,III). Exceptions to this rule include pregnancy and birth complications as well as failure to implement a maternal prophylaxis (see 4.2, 4.3 and 5.1).

\section{REFRAINING FROM BREAST FEEDING}

Breast-fed children of HIV1-positive mothers are infected twice as frequently as formula-fed children of HIV1-infected mothers. The HI viruses and HIV1-infected lymphocytes detectable in breastmilk as well as inflammation/injuries of the nipple or the mammary 
gland involving exsudation of infectious wound secretion/ blood contribute to this raised infection rate. The WHO therefore recommends that babies of HIV1-infected mothers should be fed with formula food in industrialized countries with clean drinking water. All HIV1-positive mothers should therefore be urged to avoid breast feeding $[103,104,105]$ (AI,II).

\section{Postnatal Care of THE HIV1-Exposed CHILD AND PREPARATION OF A SURVEILLANCE REGISTER}

From the 32nd week of gestation $\operatorname{IgG}$ antibodies, including also IgG antibody against HIV1, are transmitted from the mother to the fetus across the placenta. Since the conventional HIV1 test is an antibody test, all, i.e. even non-infected children of HIV1-infected mothers, are serologically HIV1-positive until the maternal antibodies disappear.

Detection of HIV1 during the first two years of life must therefore be completed using HIV1-PCR based methods. It is possible to detect either HIV1-DNA or HIV1-RNA. Up to now it is unclear which test procedure is the more sensitive with respect to the special situation of neonatal infection diagnostics. All positive HIV1 test results should be confirmed as rapidly as possible by a second blood test.

It should be noted that commercially available HIV1-PCR kits do not cover all HIV1-subtypes or mosaic viruses (not subtype B) and may provide false negative results [106]. With an HIV1-positive parent that might be infected with a subtype other than B (especially if the patient originates from outside Western Europe / North America), maternal blood must always be analyzed as a positive sample in addition to the child's blood (if possible before the onset of an anti-retroviral therapy/ prophylaxis of the mother!).

If the maternal blood is unambiguously HIV1-positive in the PCR, the result of the HIV1-PCR of the child should also be utilized. If the detection of HIV1nucleic acids fails with maternal blood (negative or borderline findings), the HIV1-PCR analysis of the child's blood can not be relied upon. Then, either a special examination must be initiated using subtypeadapted PCR primers in specialized laboratories, or the disappearance of the maternal HIV1-antibody at the end of the 2 nd year of life must be waited for in order to reliably exclude an HIV1-infection in the child.

If the HIV1-antibodies in the HIV1-exposed child persist, an HIV1-infection must be assumed. As a matter of definition, HIV1-exposed children are regarded as HIV1-negative if an HIV1-Western blot proves completely negative with normal immunoglobulin concentrations.

Amongst children of HIV1-positive mothers, two negative HIV1-PCR findings are required to exclude an HIV1-infection. The first HIV1-PCR should be performed one month after birth (in the age of 28 days: sensitivity $96 \%$, specificity $99 \%$ [129]); the second one after the third month of life, because at this timepoint the sensitivity and specificity of the HIV1-PCR is considered to be sufficiently high [107].

With the HIV1-PCR test in the first month of life a high rate of HIV1-infected children can be diagnosed.
This is important for starting prophylaxis against Pneumocystis carinii as early as possible (if possible 46 weeks after birth where HIV1-transmission has occurred) and the early-life anti-retroviral therapy in the first months of life.

With negative HIV1-PCR findings as well, disappearance of maternal antibodies in HIV1-exposed children should be documented at least once.

It must be stressed here that because of the intrauterine and postnatal exposure of a child to antiretroviral substances with still unknown long-term consequences, clinical surveillance of the children is indispensable to get aware of any long-term damage.

\section{Hotline, NOTIFICATION OF UNEXPECTED OBSERVATIONS AND EXPERIENCES}

Honorary telephone hotline for problems regarding HIV infection during pregnancy and in HIV1-exposed newborn:
Gynecologic problems:
$0178-2820282$
HIV-therapy in pregnancy:
$0178-6731661$
Pediatric problems:
$0178-4121313$

Further updating of the recommendations:

Since only little or even no results or information are available regarding the application of newer drugs or combinations of drugs during pregnancy or in newborns, all physicians involved in this work are urgently invited to inform us of any new or unexpected observations and results, e.g. by notifying us by e-mail at the address given in the "address for correspondence", or by notifying the "anti-retroviral Pregnancy Registry" (APR), the largest register for recording experiences with anti-retroviral substances during pregnancy:

Tel-no.: +1-910-256-0238

Fax: +1-910-256-0637 or +44 1895825005

Website: www.APRegistry.com

Acknowledgement: The German version of these guidelines was already published under:

Gemeinsame Erklärung der Deutschen AIDS-Gesellschaft (DAIG); der Österreichischen AIDS-Gesellschaft (ÖAG); des Kompetenznetzes HIV/AIDS sowie des Robert-KochInstitutes Berlin (RKI); der Deutschen Arbeitsgemeinschaft niedergelassener Ärzte in der Versorgung von HIV-und AIDS-Patienten (DAGNÄ); der Deutschen Gesellschaft für Kinderheilkunde und Jugendmedizin (DGKJ); der Pädiatrischen Arbeitsgemeinschaft AIDS Deutschland (PAAD); der Deutschen Gesellschaft für Gynäkologie und Geburtshilfe (DGGG); des Nationalen Referenzzentrums für Retroviren (NRZ); der Deutschen AIDS-Hilfe (DAH)

Deutsch-Österreichische Empfehlungen zur HIV-Therapie in der Schwangerschaft und bei HIV-exponierten Neugeborenen - Update 2008

Dtsch med Wochenschr 2009; 134: S40-S54

(C) Georg Thieme Verlag KG Stuttgart New York

We thank Georg Thieme Verlag KG Stuttgart · New York for the allowance for the publication of the English version. 


\section{LITERATURE}

1. Bundeszentrale für gesundheitliche Aufklärung, Köln: Aids von A bis Z; Neuauflage 2002

2. Deutsche AIDS-Hilfe e.V.: Der heutige Wissensstand 28. überarbeitete Auflage, 2002

3. Mayaux MJ, Dussaix E, Isopet J et al.: Maternal Virus Load during Pregnancy and Mother-to-Child Transmission of Human Immunodeficiency Virus Type 1: The French Perinatal Cohort Studies. J Infect Dis 1997; 175: 172-175

4. Sperling RS, Shapiro DE, Coombs RW et al.: Maternal Viral Load, Zidovudine Treatment, and the Risk of Transmission of Human Immunodeficiency Virus Type 1 from Mother to Infant. N Engl J Med 1996; 335: 1621-1629

5. Cooper ER, Charurat M, Mofenson L et al.: Combination antiretroviral strategies for the treatment of pregnant HIV-1-infected women and prevention of perinatal HIV-1 transmission. JAIDS 2002; 29:484-494

6. Poirier MC, Divi RL, Al-Harthi L et al.: Long-term mitochondrial toxicity in HIV-uninfected infants born to HIVinfected mothers. JAIDS 2003; 32: 175-183

7. Barret B, Tardieu M, Rustin P et al.: Persistent mitochondrial dysfunction in HIV-1-exposed but uninfected infants: clinical screening in a large prospective cohort. AIDS 2003; 17: 1769-1785

8. Blanche S, Tardieu M, Rustin P et al.: Persistent mitochondrial dysfunction and perinatal exposure to antiretroviral nucleoside analogues. Lancet 1999; 354: 1084-1089

9. Poirier MC, Patterson TA, Slikker Jr. W, Olivero OA: Incorporation of $3^{\prime}$-Azido-3'-Deoxythymidine (AZT) into fetal DNA and fetal tissue distribution of drug after infusion of pregnant late-term rhesus macaques with a humanequivalent AZT dose. JAIDS 1999; 22: 477-483

10. Meng Q, Walker DM, Olivero OA et al.: Zidovudine-didanosine coexposure potentiates DNA incorporation of zidovudine and mutagenesis in human cells. Proc Natl Acad Sci USA 2000; 97: 12667-12671

11. Scalfaro P, Chesaux JJ, Buchwalder PA et al.: Severe transient neonatal lactic acidosis during prophylactic zidovudine treatment. Intensive Care Med 1998; 24: 247-250

12. European Collaborative Study: Exposure to antiretroviral therapy in utero or early life: the health of uninfected children born to HIV-infected women. JAIDS 2003; 32: 380387

13. Wahn V: Routinemäßige Gabe von Zidovudin an HIV-infizierte Schwangere. Dt Ärztebl 1995; 92:A-3397-3398

14. Frenkel LM, Cowles MK, Shapiro DE et al.: Analysis of the Maternal Components of the AIDS Clinical Trial Group 076 Zidovudine Regimen in the Prevention of Mother-to-Infant Transmission of Human Immunodeficiency Virus Type 1. J Infect Dis 1997; 175: 971-974

15. Landesmann SH, Kalish LA, Burns DN et al.: Obstetrical Factors and The Transmission of Human Immunodeficiency Virus Type 1 from Mother to Child. N Engl J Med 1996; 334: 1617-1623

16. Mandelbrot L, Le Chenadec J, Berrebi A et al.: Perinatal HIV-1 Transmission. Interaction between Zidovudine Prophylaxis and Mode of Delivery in the French Perinatal Cohort. JAMA 1998; 280: 55-60

17. Pitt J, Brambilla D, Reichelderfer P et al.: Maternal Immunologic and Virologic Risk Factors for Infant Human Immunodeficiency Virus Type 1 Infection: Findings from the Women and Infants Transmission Study. J Infect Dis 1997; 175: 567-575

18. Rokos K, Wang H, Seeger J et al.: Transport of Viruses Through Fetal Membranes: An In Vitro Model of Perinatal Transmission. J Med Virology 1998; 54: 313-319

19. The European Collaborative Study: Vertical transmission of HIV-1: maternal immune status and obstetric factors. AIDS 1996; 10: 1675-1681
20. The European Collaborative Study: Immunological markers in HIV-infected pregnant women. AIDS 1997; 11: 1859-1865

21. Tuomala RE, O’Driscoll PT, Bremer JW et al.: Cell-associated genital tract virus and vertical transmission of human immunodeficiency virus type 1 in antiretroviral-experienced women. JID 2003; 187: 375-384

22. Burns DN, Landesman S, Wright, DJ et al.: Influence of other maternal variables on the relationship between maternal virus load and mother-to-infant transmission of human immunodeficiency virus type 1. J Infect Dis 1997; 175:1206-1210

23. Gaillard P, Verhofstede C, Mwanyumba F et al.: Exposure to HIV-1 during delivery and mother-to-child transmission. AIDS 2000; 14: 2341-2348

24. Wright TC Jr, Subbarao S, Ellerbrock TV et al.: Human immunodeficiency virus 1 expression in the female genital tract in association with cervical inflammation and ulceration. Am J Obstet Gynecol. 2001; 184: 279-285

25. Mwanyumba F, Gaillard P, Inion I et al.: Placental inflammation and perinatal transmission of HIV-1. JAIDS 2002; 29: 262-269

26. Kind Ch, Rudin Ch, Siegrist C et al.: Prevention of vertical HIV transmission: additive protective effect of elective Cesarean section and zidovudine prophylaxis. AIDS 1998; 12: $205-210$

27. Schäfer APA: Die HIV-Infektion in Geburtshilfe und Gynäkologie. Gynäkologe 1996; 29:129-137

28. Schäfer A, Friese K, Lauper U et al.: Influence of cesarean section before parturition and antiretroviral prophylaxis on the materno-fetal transmission of HIV. 12th World AIDS Conference Geneva, June 28-July 3 1998, Poster LB 12466

29. Salzberger B, Marcus U, Vielhaber B et al.: German-Austrian recommendations for the antiretroviral therapy of HIV-infection (status May 2004). Eur J Med Res. 2004; 9(11): 491-504

URL: http://www.daignet.de unter Leitlinien

30. Coll O, Fiore S, Floridia M et al.: Pregnancy and HIV infection: A european consensus on management. AIDS 2002; 16 (Suppl 2): S1-18

31. CDC Public Health Service Task Force: Recommendations for the Use of Antiretroviral Drugs in Pregnant Women Infected with HIV-1 for Maternal Health and for Reducing Perinatal HIV-1 Transmission in the United States. MMWR 1998; 47/ RR2

32. CDC: Report of the NIH Panel to Define Principles of Therapy of HIV Infection and Guidelines for the Use of Antiretroviral Agents in HIV-Infected Adults and Adolescents. MMWR 1998; 47/ RR-5

33. Justman JE, Benning L, Danoff A et al.: Protease inhibitor use and the incidence of diabetes mellitus in a large cohort of HIV-infected women. JAIDS 2003; 32: 298-302

34. Lorenzi P, Spicher VM, Laubereau B et al. (Swiss HIV Cohort Study, the Swiss Collaborative HIV and Pregnancy Study, and the Swiss Neonatal HIV Study): Antiretroviral therapies in pregnancy: maternal, fetal and neonatal effects. AIDS 1998; 12 (18): F 241-247

35. Wimalasundera RC, Larbalestier N, Smith JH et al.: Preeclampsia, antiretroviral therapy, and immune reconstitution. Lancet 2002, 360: 1152-1154

36. Tuomala RE, Shapiro DE, Mofenson LM et al.: Antiretroviral therapy during pregnancy and the risk of an adverse outcome. N Engl J Med 2002; 346:18631870

37. Conley LJ, Ellerbrock TV, Bush TJ et al.: HIV-1 infection and risk of vulvovaginal and perianal condylomata acuminata and intraepithelial neoplasia: a prospective cohort study. Lancet 2002; 359: 108-113

38. Vandamme AM, Sonnerborg A, Ait-Khaled M et al.: Updated European recommendations for the clinical use of 
HIV drug resistance testing. Antivir Ther 2004; 9(6): 829848

39. Welles SL, Pitt J, Colgrove R and The Women and Infants Transmission Study Group: HIV-1 genotypic zidovudine drug resistance and the risk of maternal-infant transmission in the Women and Infants Transmission Study. AIDS 2000; 14:263-271

40. Duwe S, Brunn M, Altmann D et al.: Frequency of genotypic and phenotypic drug-resistant HIV-1 among therapy-naive patients of the German Seroconverter Study. JAIDS 2001; 26: 266-273

41. Eastman PS, Shapiro DE, Coombs RW et al.: Maternal Viral Genotypic Zidovudine Resistance and Infrequent Zidovudine Therapy to Prevent Perinatal Transmission of Human Immunodeficiency Virus Type 1 in Pediatric Clinical Trial Protocol 076. J Infect Dis 1998; 177: 557-564

42. Mandelbrot L, Landreau-Mascaro A, Rekacewicz C et al.: Lamivudine-Zidovudine combination for prevention of maternal-infant transmission of HIV-1. JAMA 2001; 285 : 2083-2093

43. Jackson JB, Becker-Pergola G, Guay LA et al.: Identification of the $\mathrm{K} 103 \mathrm{~N}$ resistance mutation in Ugandan women receiving nevirapine to prevent HIV-1 vertical transmission. AIDS 2000; 14: F111-F115

44. Eshleman SH, Hoover DR, Chen S et al.: Nevirapine (NVP) resistance in women with HIV-1 subtype C, compared with subtypes $A$ and $D$, after the administration of single-dose NVP. J Infect Dis 2005; 192(1): 30-36

45. Sustiva Capsules Product Monograph 1998

46. BMS Warning Letter, 5. January 2001

47. Rich KC, Siegel JN, Jennings C et al.: CD4+ lymphocytes in perinatal human immunodeficiency virus (HIV) infection: evidence for pregnancy-induced immune depression in uninfected and HIV-infected women. J Infect Dis 1995; 172: 1221-1227

48. Kosel BW, Beckerman KP, Hayashi S et al.: Pharmacokinetics of nelfinavir and indinavir in HIV-1-infected pregnant women. AIDS 2003; 17: 1195-1199

49. Mirochnick M, Fenton T, Gagnier P et al.: Pharmacokinetics of nevirapine in human immunodeficiency virus type 1 -infected pregnant women and their neonates. Pediatric AIDS Clinical Trials Group Protocol 250 Team. J Infect Dis 1998; 178: 368-374

50. Wang Y, Livingston E, Patil S, et al.: Pharmacokinetics of didanosine in antepartum and postpartum human immunodeficiency virus-infected pregnant women and their neonates: an AIDS clinical trials group study. J Infect Dis 1999; 180: 1536-1541

51. Qian M, Bui T, Ho RJY et al.: Metabolism of 3'-Azido-3'Deoxythymidine (AZT) in Human Placental Trophopblasts and Hofbauer Cells. Biochemical Pharmacology 1994; 48: 383-389

52. Agbaria R, Manor E, Barak J et al.: Phosphorylation of 3'Azidothymidine in maternal and fetal peripheral blood mononuclear cells during gestation and and at term. JAIDS 2003; 32: 477-481

53. Taylor GP, Lyall EGH, Back D et al.: Pharmacological implications of lengthened in-utero exposure to nevirapine. Lancet 2000; 355: 2134-2135

54. Marzolini C, Rudin C, Decosterd LA et al.: Transplacental passage of protease inhibitors at delivery. AIDS 2002; 16 : 889-893

55. Mirochnick M, Dorenbaum A, Holland D et al.: Concentrations of protease inhibitors in cord blood after in utero exposure. Pediatr Infect Dis J 2002; 21(9): 835838

56. Mirochnick M, Dorenbaum A, Blanchard S et al.: Predose infant nevirapine concentration with the two-dose intrapartum neonatal nevirapine regimen: association with timing of maternal intrapartum nevirapine dose. JAIDS 2003; 33(2): 153-156
57. Antiretroviral Pregnancy Registry Steering Committee: Antiretroviral Pregnancy Registry International Interim Report for 1 January 1989 through 31 July 2007; Issued Dec 2007 available from url:www.apregistry.com

58. Larsen WJ: Human Embryology. New York: Churchill Livingstone, 1993

59. Wilson JD, Frazer FC (Hrsg.): Handbook of Teratology, Vol. I. New York: Plenum Press, 1977

60. Spielmann H, Steinhoff R, Schaefer C et al.: Arzneiverordnung in Schwangerschaft und Stillzeit. 5. Aufl., Stuttgart, Gustav Fischer,1998

61. Connor EM, Sperling RS, Gelber R et al.: Reduction of Maternal-Infant Transmission of Human Immunodeficiency Virus Type 1 with Zidovudine Treatment. N Engl J Med 1994; 331:1173-1180

62. Chuachoowong R, Shaffer N, Siriwasin W et al.: Shortcourse antenatal zidovudine reduces both cervicovaginal human immunodeficiency virus type 1 RNA levels and risk of perinatal transmission. J Inf Dis 2000; 181: 99106

63. Lallemant M, Jourdain G, Le Coeur S et al.: A trial of shortened zidovudine regimens to prevent mother-tochild transmission of human immunodeficiency virus type 1. N Eng J Med 2000; 343: 982-991

64. Wade NA, Birkhead GS, Warren BL et al.: Abbreviated regimens of zidovudine prophylaxis and perinatal transmission of the human immunodeficiency virus. $\mathrm{N}$ Engl J Med 1998; 339: 1409-1414

65. Mbori-Ngacha D, Richardson BA, Overbaugh J et al.: Short-term effect of zidovudine on plasma and genital human immunodeficiency virus type 1 and viral turnover in these compartments. J Virol 2003; 77: 7702-7705

66. Ekpini RA, Nkengasong JN, Sibailly T et al.: Changes in plasma HIV-1-RNA viral load and CD4 cell counts, and lack of zidovudine resistance among pregnant women receiving short-course zidovudine. AIDS 2002; 16: 625-630

67. Sabbatini F, Prati F, Borghi V. et al. : Congenital pyelectasis in children born from mothers on Tenofovir containing therapy during pregnancy : report of two cases. Infection 2007; 35: 474-476

68. Bardeguez AD, Shapiro DE, Mofenson LM et al.: Effect of cessation of zidovudine prophylaxis to reduce vertical transmission on maternal HIV disease progression and survival. JAIDS 2003; 32: 170-181

69. Clarke JR, Braganza R, Mirza A et al.: Rapid development of genotypic resistance to lamivudine when combined with zidovudine in pregnancy. J Med Virol 1999; 59:364-368

70. O'Sullivan M, Boyer P, Scott G et al.: The pharmacokinetics and safety of zidovudine in the third trimester of pregnancy for women infected with human immunodeficiency virus and their infants: Phase I Acquired Immunodeficiency Syndrome Clinical Trials Group study (protocol 082). Am J Obstet Gynecol 1993; 168: 15101516

71. Garcia PM, Kalish LA, Pitt J et al.: Maternal levels of plasma human immunodeficiency virus type 1 RNA and the risk of perinatal transmission. N Eng J Med 1999; 341: 394-402

72. Mofenson LM, Lambert JS, Stiehm ER et al.: Risk factors for perinatal transmission of human immunodeficiency virus type 1 in women treated with zidovudine. N Eng J Med 1999; 341: 385-393

73. The European Collaborative Study: Maternal viral load and vertical transmission of HIV-1: an important factor but not the only one. AIDS 1999; 13: 1377-85

74. Shaffer N, Roongpisuthipong A, Siriwasin W et al.: Maternal virus load and perinatal human immunodeficiency virus type 1 subtype $\mathrm{E}$ transmission, Thailand. J Inf Dis 1999; 179: 590-599

75. Semprini AE: An international randomised trial of mode of delivery in HIV infected women. 12th World AIDS 
Conference Geneva, June 28-July 3 1998, Poster LB 23599

76. The International Perinatal HIV Group: The mode of delivery and the risk of vertical transmission of human immunodeficiency virus type 1 - a meta-analysis of 15 prospective cohort studies. N Eng J Med 1999; 340: 977-987

77. CDC: Recommendations of the U-S. Public Health Service Task Force on the Use of Zidovudine to Reduce Perinatal Transmission of Human Immunodeficiency Virus. MMWR 1994; 43/RR-11

78. Grosch-Wörner I, Schäfer A, Obladen M et al.: An effective and safe protocol involving zidovudine and caesarean section to reduce vertical transmission of HIV-1 infection. AIDS 2000; 14: 2903-2911

79. Burns DN, Landesman S, Muenz LR et al.: Cigarette smoking, premature rupture of membranes and vertical transmission of HIV1 among women with low CD4+ levels. JAIDS 1994; 7: 718-726

80. Wensing MJ, Boucher CAB, van Kasteren M et al.: Prevention of mother-tochild.transmission of multi-drug resistant HIV-1 using maternal therapy with both enfuvirtide and tipranavir. AIDS 2006; 20: 1465-1467

81. Stringer JSA, Sinkala M, Chapman V et al.: Timing of the maternal drug dose and risk of perinatal HIV transmission in the setting of intrapartum and neonatal single-dose nevirapine. AIDS 2003; 17: 1659-1665

82. Taha TE, Kumwenda NI, Hoover DR et al.: Nevirapine and zidovudine at birth to reduce perinatal transmission of HIV in an African setting: a randomized controlled trial. JAMA 2004; 292(2): 202-209

83. Lallemant M, Jourdain G, Le Coeur S et al. Perinatal HIV Prevention Trial (Thailand) Investigators: Single-dose perinatal nevirapine plus standard zidovudine to prevent mother-to-child transmission of HIV-1 in Thailand. N Engl J Med. 2004; 351(3): 217-228

84. Dabis F, Bequet L, Ekouevi DK et al.: ANRS 1201/1202 DITRAME PLUS Study Group: Field efficacy of zidovudine, lamivudine and single-dose nevirapine to prevent peripartum HIV transmission. AIDS 2005; 19(3): 309-318.

85. Garcia-Tejedor A, Perales A, Maiques V: Duration of ruptured membranes and extended labor are risk factors for HIV transmission. Int J Gynaecol Obstet. 2003; 82(1): 17 23.

86. Deutsch-Österreichische Empfehlungen zur postexpositionellen Prophylaxe nach HIV-Exposition (September 2004) URL: http://www.rki.de

87. Guay LA, Musoke P, Fleming T et al: Intrapartum and neonatal single dose nevirapine compares with zidovudine for prevention of mother-to-child transmission of HIV-1 in Kampala, Uganda. HIVNET 012 randomized trial. Lancet 1999; 354: 795-802

88. Moodley D, Moodley J, Coovadia H et al.: A multicenter randomized controlled trial of nevirapine versus a combination of zidovudine and lamivudine to reduce intrapartum and early postpartum mother-to-child transmission of human immunodeficiency virus type 1 . J Infect Dis 2003; 187: 725-735

89. Flys T, Nissley DV, Claasen CW et al.: Sensitive drug-resistance assays reveal long-term persistence of HIV-1 variants with the K103N nevirapine (NVP) resistance mutation in some women and infants after the administration of single-dose NVP: HIVNET 012. J Infect Dis 2005; 192(1): 24-29

90. Marcus U: AIDS und HIV-Infektionen bei Frauen und Kindern in Deutschland. Bundesgesundheitsbl - Gesundheitsforsch - Gesundheitsschutz 1999; 42: 553-557

91. Shapiro D, Tuomala R, Samelson R et al. Abstract 12953, 9th Conference on Retroviruses and Opportunistic Infections, Seattle 2002

92. Ioannidis JPA, Abrams EJ, Ammann A et al.: CM: Perinatal transmission of human immunodeficiency virus type 1 by pregnant women with RNA virus loads $<1000$ copies/ml. J Inf Dis 2001; 183: 539-545

93. Mandelbrot L, Burgard M, Teglas J-P et al.: Frequent detection of HIV-1 in the gastric aspirates of neonates born to HIV-infected mothers. AIDS 1999; 13: 2143-2149

94. Debiaggi M, Zara F, Spinillo A et al.: Viral excretion in cervicovaginal secretions of HIV-1-infected women receiving antiretroviral therapy. Eur J Microbiol Infect Dis 2001; 20: 91-96

95. Ellerbrock TV, Lennox JL, Clancy KA et al.: Cellular replication of human immunodeficiency virus type 1 occurs in vaginal secretions. J Infect Dis 2001, 184: 28-36

96. Si-Mohamed A, Kazatchkine MD, Goujon C et al.: Selection of drug-resistant variants in the female genital tract of human immunodeficiency virus type 1 -infected women receiving antiretroviral therapy. J Infect Dis 2000, 182: 112122

97. Avidan MS, Groves P, Blott M et al.: Low complication rate associated with cesarean section under spinal anesthesia for HIV-1-infected women on antiretroviral therapy. Anesthesiology 2002; 97(2): 320-324

98. Read J, Tuomala R, Kpamegan E et al.: Mode of delivery and postpartum morbidity among HIV-infected women: the women and infants transmission study. JAIDS 2001; 26: $236-245$

99. Rodriguez EJ, Spann C, Jamieson D et al.: Postoperative morbidity associated with cesarean delivery among human immunodeficiency virus-seropositive women. Am J Obstet Gynecol 2001, 184:1108-1111

100. Watts DH, Lambert JS, Stiehm ER et al.: Complications according to mode of delivery among human immunodeficiency virus-infected women with CD4 lymphocyte counts of $<$ or $=500 /$ microL. Am J Obstet Gynecol 2000; 183:100-107

101. European Collaborative Study and the Swiss Mother + Child HIV Cohort Study: Combination antiretroviral therapy and duration of pregnancy. AIDS 2000; 14: 2913-2920

102. Nduati R, John G, Mbori-Ngacha D et al.: Effect of breastfeeding and formula feeding on Transmission of HIV-1. JAMA 2000; 283: 1167-1174

103. Van de Perre P.: Transmission of human immunodeficiency virus type 1 through breast-feeding: how can it be prevented? J Infect Dis. 1999; 179 Suppl 3: S405-407

104. Nduati RW, John GC, Richardson BA et al.: Human immunodeficiency virus type 1 infected cells in breast milk. Infect Dis 1995; 172: 1461-1468

105. Thiry L, Spencer-Goldberger S, Jonckheer T et al.: Isolation of AIDS virus from cell-free breastmilk of three healthy virus carriers. Lancet 1985 ii: 891-892

106. Haas J, Geiss M, Böhler T et al.: False-negative polymerase chain reaction-based diagnosis of human immunodeficiency virus type 1 in children infected with HIV strains of African origin. J Infect Dis 1996; 174: 224-225

107. Rossi P, et al.: Early diagnosis of HIV infection in infants - Report of a consensus workshop, Siena, Italy, January 17-18, 1992. JAIDS 1992; 5: 1168-1178

108. CENTERS OF DISEASE CONTROL: Guidelines for the use of antiretroviral agents in pediatric HIV infection. MMWR 1998; 47: 1-43; URL http://www.hivatis.org

109. Capparelli EV, Mirochnick M, Dankner WM et al.: Pediatric AIDS Clinical Trials Group 331 Investigators: Pharmacokinetics and tolerance of zidovudine in preterm infants. J Pediatr 2003; 142(1): 47-52

110. Maiques V, Garcia-Tejedor A, Perales A et al: HIV detection in amniotic fluid samples. Amniocentesis can be performed in HIV pregnant women? Eur J Obstet Gynecol Reprod Biol 2003; 108(2): 137-141

111. Davies G, Wilson RD, Desilets V et al.: Society of Obstetricians and Gynaecologists of Canada: Amniocentesis 
and women with hepatitis B, hepatitis C or human immunodeficiency virus. J Obstet Gynaecol Can 2003; 25(2): 145-148, 149-152

112. Poirier MC, Olivero OA, Walker DM et al.: Perinatal genotoxicity and carcinogenicity of anti-retroviral nucleoside analog drugs. Toxicol Appl Pharmacol 2004; 199(2): 151-161

113. Mirochnick M, Capparelli E et al.: Pharmacokinetics of antiretrovirals in pregnant women. Clin Pharmacokinet 2004; 43(15): 1071-1087

114. Lyons FE, Coughlan S, Byrne CM et al.: Emergence of antiretroviral resistance in HIV-positive women receiving combination antiretroviral therapy in pregnancy. AIDS 2005; 19(1): 63-67

115. Nolan M, Fowler MG, Mofenson LM. Antiretroviral prophylaxis of perinatal HIV-1 transmission and the potential impact of antiretroviral resistance. J Acquir Immune Defic Syndr. 2002; 30(2): 216-29.

116. Thorne C, Patel D, Newell ML: Increased risk of adverse pregnancy outcomes in HIV-infected women treated with highly active antiretroviral therapy in Europe. AIDS 2004; 18(17): 2337-2339

117. Fiore S, Newell ML, Thorne C: European HIV in Obstetrics Group: Higher rates of post-partum complications in HIV-infected than in uninfected women irrespective of mode of delivery. AIDS 2004; 18(6): 933-938

118. Marcollet A, Goffinet F, Firtion G et al: Differences in postpartum morbidity in women who are infected with the human immunodeficiency virus after elective cesarean delivery, emergency cesarean delivery, or vaginal delivery. Am J Obstet Gynecol 2002; 186(4): 784-789

119. Kovacs A, Wasserman SS, Burns D et al.: DATRI Study Group; WIHS Study Group: Determinants of HIV-1 shedding in the genital tract of women. Lancet 2001; 358(9293): 1593-1601

120. Fiore JR, Suligoi B, Saracino A et al.: Correlates of HIV1 shedding in cervicovaginal secretions and effects of antiretroviral therapies. AIDS 2003; 17(15): 2169-2176

121. Brennan-Benson p, Pakianathan M, Rice P et al.: Enfurvitide prevents vertical transmission of multidrug-resistant HIV-1 in pregnancy but does not cross plcenta. AIDS 2006; 20: 297-299

122. Chaix ML, Dabis F, Ekouevi D et al.: Addition of 3 Days of ZDV+3TC Postpartum to a Short Course of ZDV+3TC and Single-dose NVP Provides Low Rate of NVP Resistance Mutations and High Efficacy in Preventing Peri-partum HIV-1 Transmission: ANRS DITRAME Plus, Abidjan, Côte d'Ivoire. 12th CROI, Boston 2005, Abstr. 72LB

123. Ripamonti D, Cattaneo D, Maggiolo F et al.: Atazanavir plus low.dose ritonavir in pregnancy : pharmacokinetics and placental transfer. AIDS $2007 ; 21: 2409-2415$

124. Ioannidis JP, Contopoulos-Ioannidis DG: Maternal viral load and the risk of perinatal transmission of HIV-1. N Engl J Med. 1999; 341(22): 1698-1700

125. Chappuy H, Treluyer JM, Rey E et al.: Maternal-fetal transfer and amniotic fluid accumulation of protease inhibitors in pregnant women who are infected with human immunodeficiency virus. Am J Obstet Gynecol. 2004; 191(2): 558-562

126. Feiterna-Sperling C, Piening T, Casteleyn S: Use of lopinavir $(\mathrm{LPV} / \mathrm{r})$ during pregnancy Eur J Med Res 10 Supplement II, S. 89 P161.

127. Meyohas MC, Lacombe K, Carbonne B et al.: Enfuvirtide prescription at the end of pregnancy to a multi-treated HIV-infected woman with virological breakthrough. AIDS 2004; 18(14): 1966-1968

128. Morris A, Juethner S, Theroux E: Atazanavir use in pregnancy. Third International AIDS Society Conference on HIV Pathogenesis and Therapy, Rio, poster presentation TuPe5.2p01, 2005.
129. Dunn DT, Brandt CD, Kirvine A et al.: The sensitivity of HIV1-DNA polymerase chain reaction in the neonatal period and the relative contributions of intra-uterine and intra-partum transmission. AIDS 1995; 9(9): F7-11

130. Chaisilwattana P, Chokephaibulkit K, Chalermchockcharoenkit A et al.: Short-course therapy with zidovudine plus lamivudine for prevention of mother-to-child transmission of human immunodeficiency virus type 1 in Thailand. Clin Infect Dis 2002 35(11): 1405-1413

131. European collaborative study. HIV-infected pregnant women and vertical transmission in Europe since 1986. AIDS. 2001 15(6): 761-770

132. European Collaborative Study. Mother-to-child transmission of HIV infection in the era of highly active antiretroviral therapy. Clin Infect Dis 2005 40(3): 458-465

133. Ananworanich J, Siangphoe U, Hill A et al.: Highly active antiretroviral therapy (HAART) retreatment in patients on CD4-guided therapy achieved similar virologic suppression compared with patients on continuous HAART: the HIV Netherlands Australia Thailand Research Collaboration 001.4 study. JAIDS 2005; 39(5): 523-529

134. Pellegrin I, Thiebaut R, Blanco P et al.: Can highly active antiretroviral therapy be interrupted in patients with sustained moderate HIV RNA and $>400 \mathrm{CD} 4(+)$ cells/microl? Impact on immunovirological parameters. J Med Virol 2005; 77(2): 164-172

135. Tarantal AF, Marthas ML, Shaw JP et al.: Administration of 9-[2-(R)-(phosphonomethoxy)propyl] adenine (PMPA) to gravid and infant rhesus macaques (Macaca mulatta): safety and efficacy studies. J Acquir Immune Defic Syndr Hum Retrovirol. 1999: 20: 323-333.

136. Hughes S, Hughes A, Brothers C et al. on behalf of the CNA106030 Study Team. PREDICT-1 (CNA106030): the first powered, prospective trial of pharmacogenetic screening to reduce drug adverse events. Pharm Stat. 2007 May 29; [Epub ahead of print]

137. Warszawski J, Tubiana R, Le Chenadec J et al. Mother to child HIV transmission despite antiretroviral therapy in the ARNS French Perinatal Cohort: AIDS 2008; 22: 289-299

138. Mofenson LM. Efavirenz reclassified as FDA pregnancy category D. AIDS Clin Care. 2005; $17(2): 17$.

139. Strategies for Management of Antiretroviral Therapy (SMART) Study Group, El-Sadr WM, Lundgren JD, Neaton JD, Gordin F, Abrams D, Arduino RC, Babiker A, Burman W, Clumeck N, Cohen CJ, Cohn D, Cooper D, Darbyshire J, Emery S, Fätkenheuer G, Gazzard B, Grund B, Hoy J, Klingman K, Losso M, Markowitz N, Neuhaus J, Phillips A, Rappoport C. CD4+ count-guided interruption of antiretroviral treatment. $\mathrm{N}$ Engl J Med. 2006 355(22):2283-96

140. Gingelmaier A, Hollwitz B, Casteleyn S et al. Schwangerschaftsverlauf und kindliches Outcome bei 599 HIVexponierten Schwangerschaften an deutschen Schwerpunktzentren 1999-2003. Geburtshilfe und Frauenheilkunde 2005, 65: 1058-1063

141. Sadiq ST, Fredericks S, Khoo SH et al. Efavirenz detectable in plasma 8 weeks after stopping therapy and subsequent development of non-nucleoside reverse transcriptase inhibitor-associated resistance. AIDS. 2005; 19(15):1716-7.

\section{Address for correspondence:}

Dr. med. Bernd Buchholz

University Medical Centre Mannheim, Pediatric Clinic

Theodor-Kutzer-Ufer 1-3

68167 Mannheim, Germany

Tel.: $\quad+49-(0) 621-383-1278$

Fax: +49-(0)621-383-3829

E-mail: bernd.buchholz@umm.de 